Supporting Information for:

\title{
Vanadium-Catalyzed Asymmetric Oxidation of $\alpha$-Hydroxy Esters Using Molecular Oxygen as Stoichiometric Oxidant
}

\author{
Alexander T. Radosevich, Christine Musich, and F. Dean Toste* \\ Center for New Directions in Organic Synthesis, Department of Chemistry, University of California, Berkeley, \\ California 94720
}

Materials and Methods. Solvents for surveys in Table 1 and Table S1 were freshly distilled before use. Acetone for the vanadium-catalyzed asymmetric oxidation reactions was used as received from EMD Chemicals. $\mathrm{VO}(\mathrm{O} i \mathrm{Pr})_{3}, \mathrm{VO}(\mathrm{acac})_{2}, \mathrm{VOCl}_{3}$, and $\mathrm{V}_{2} \mathrm{O}_{5}$ were purchased from Aldrich Chemical and used without further purification. Salicylaldehyde derivatives and chiral amino alcohols were purchased from Aldrich Chemical, except 3-(1-adamantyl)-5-methylsalicyladehyde ${ }^{1}$ and 3-tert-butyl-5-nitrosalicylaldehyde. ${ }^{2}$ Chiral ligands employed in Table 1 were prepared by condensation of the corresponding aldehydes and amino alcohols in methanol. ${ }^{3}$ Available racemic $\alpha$-hydroxy esters were purchased from commercial vendors and purified as necessary before use. Noncommercially available $\alpha$-hydroxy esters were prepared as described below. Available enantiopure $\alpha$-hydroxy esters were purchased from commercial vendors for analytical comparison. Oxygen and nitrogen atmospheres were maintained via a Tygon gas line vented through an oil bubbler. Argon and hydrogen atmospheres were maintained via balloon pressure. Thin-layer chromatography (TLC) analysis of reaction mixtures was performed using Merck silica gel $60 \mathrm{~F}_{254}$ TLC plates. Flash column chromatography was carried out on Merck 60 silica gel $(32-63 \mu \mathrm{m}) .{ }^{1} \mathrm{H}$ and ${ }^{13} \mathrm{C}$ NMR spectra were recorded with Bruker AVB-400, AVQ-400, and AV-300 spectrometers and referenced to $\mathrm{CHCl}_{3}(7.26 \mathrm{ppm})$ unless otherwise noted. ${ }^{51} \mathrm{~V}$ NMR spectra were recorded with a Bruker AVB-400 spectrometer in acetone- $d_{6}$ and referenced to $\mathrm{VOCl}_{3}(0 \mathrm{ppm})$ as an external standard. X-band EPR spectra were recorded in acetone solution using a $5 \mathrm{~mm}$ o.d. quartz tube with a Bruker EMX-300 spectrometer operating at ambient temperature. Analytical chiral HPLC was performed with a Shimadzu VP Series Chiral HPLC with detection at 210, 254, and $280 \mathrm{~nm}$ using Chiralcel OJ and OD columns. Analytical GC was carried out with a Hewlett Packard HP 6850 GC equipped with an Agilent DB-WAX (30.0 m x $0.25 \mathrm{~mm}$ ) column for achiral separation and a Chiraldex G-TA (30.0 $\mathrm{m} \times 0.25 \mathrm{~mm}$ ) column for chiral separation.

CAUTION: Organic solvents under oxygen atmosphere are extremely flammable. Although we have never experienced an accident, caution should always be exhibited to avoid ignition.

\footnotetext{
${ }^{1}$ Dossetter, A.G.; Jamison, T.F.; Jacobsen, E.N. Angew. Chem. Int. Ed. 1999, 38, 2398.

${ }^{2}$ Cogan, D.A.; Liu, G.; Kim, K.; Backes, B.J.; Ellman, J.A. J. Am. Chem. Soc. 1998, 120, 8011.

${ }^{3}$ Liu, G.; Cogan, D.A.; Ellman, J.A. J. Am. Chem. Soc. 1997, 119, 9913.
} 


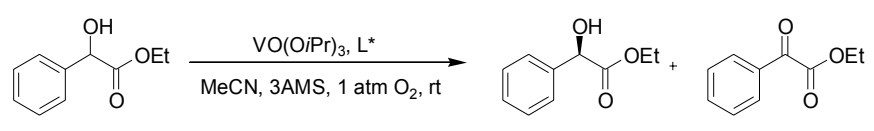

General Procedure for the Asymmetric Oxidation

Reaction of Ethyl Mandelate - Ligand Screening

Experiments. A 2-dram vial equipped with a magnetic stir bar was charged with powdered molecular sieves (3ÅMS, $0.15 \mathrm{~g}$ ) then purged with a flow of oxygen. A solution of the appropriate ligand $(0.025 \mathrm{mmol}, 0.11$ equiv, Figure $\mathrm{S} 1)$ in dry acetonitrile $(0.5 \mathrm{~mL})$ was delivered via syringe. $\mathrm{VO}(\mathrm{O} i \mathrm{Pr})_{3}(4.7 \mu \mathrm{L}, 0.020 \mathrm{mmol}, 0.08$ equiv) was then added via syringe, and the resulting dark mixture was stirred under oxygen for $10 \mathrm{~min}$. ( \pm )-Ethyl mandelate $(50 \mathrm{mg}, 0.25 \mathrm{mmol})$ and hexamethylbenzene $(5 \mathrm{mg}$, internal standard) were then introduced via syringe as a solution in dry acetonitrile $(0.5 \mathrm{~mL})$. The reaction mixture was stirred at ambient temperature for $3 \mathrm{~h}$, and then filtered over silica with diethyl ether eluent. The filtrate was analyzed directly by chiral GC for conversion and enantiomeric excess (Chiraldex G-TA; $90{ }^{\circ} \mathrm{C}$ hold 0 min, then 10 ${ }^{\circ} \mathrm{C} / \mathrm{min}$ to $140{ }^{\circ} \mathrm{C} ; 2.0 \mathrm{~mL} / \mathrm{min}$ He carrier gas), $\mathrm{t}_{\mathrm{R}} 9.60 \mathrm{~min}$ ( $S$-alcohol), $10.02 \mathrm{~min}$ ( $R$-alcohol), 10.96 (ketone).

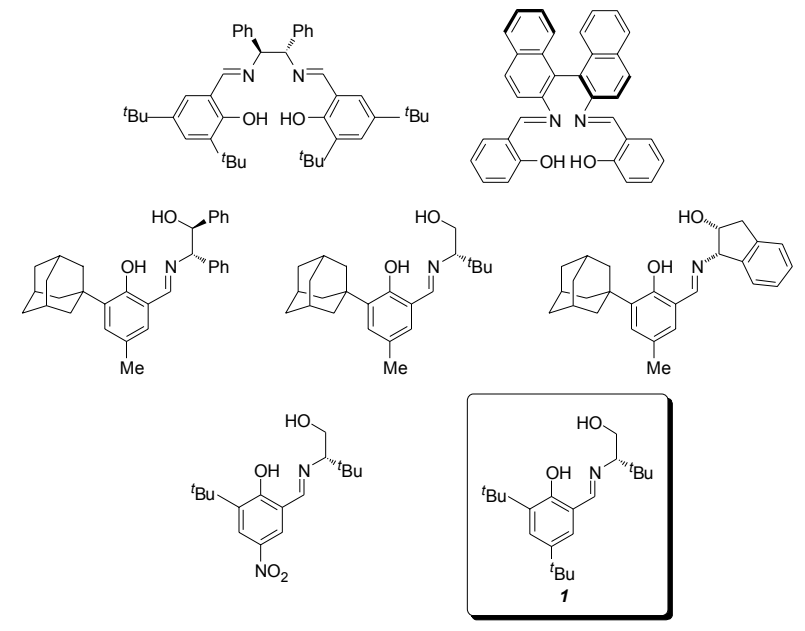

Figure S1. Chiral Salicylaldimine Ligands for Vanadium-Catalyzed Asymmetric Oxidation

General Procedure for the Asymmetric Oxidation Reaction of Ethyl Mandelate - Solvent and Vanadium Source Screening Experiments (Table S1). A 2-dram vial containing a magnetic stir bar was charged with powdered molecular sieves (3ÅMS, $0.15 \mathrm{~g})$ as necessary. A solution of ligand 1 (0.025 mmol, 0.11 equiv) in $0.5 \mathrm{~mL}$ of solvent was then delivered via syringe, followed by the vanadium species $(0.020 \mathrm{mmol}, 0.08$ equiv $)$. The resulting mixture was stirred under oxygen for $15 \mathrm{~min}$. ( \pm )-Ethyl mandelate (50 mg, $0.25 \mathrm{mmol})$ and hexamethylbenzene ( $5 \mathrm{mg}$, internal standard) were then introduced via syringe as a solution in solvent $(0.5 \mathrm{~mL})$. The reaction mixture was stirred at ambient temperature for $3 \mathrm{~h}$, and then filtered over silica with diethyl ether eluent. The filtrate was directly analyzed by chiral GC for conversion and enantiomeric excess (Chiraldex G-TA; 90 
${ }^{\circ} \mathrm{C}$ hold $0 \mathrm{~min}$, then $10^{\circ} \mathrm{C} / \mathrm{min}$ to $140{ }^{\circ} \mathrm{C}$ hold $10 \mathrm{~min} ; 2.0 \mathrm{~mL} / \mathrm{min}$ He carrier gas $), \mathrm{t}_{\mathrm{R}} 9.60 \mathrm{~min}(S$-alcohol $), 10.02$ $\min (R$-alcohol), 10.96 (ketone).

Table S1. Effect of Solvent and Vanadium Source on the Kinetic Resolution of Ethyl Mandelate ${ }^{a}$

\begin{tabular}{|c|c|c|c|c|}
\hline \multicolumn{5}{|c|}{1 atm. $\mathrm{O}_{2}$, rt } \\
\hline entry & conditions & conversion $^{b}$ & ee $\mathrm{ROH}$ & $\mathrm{s}^{c}$ \\
\hline 1. & $\mathrm{MeCN}, \mathrm{VO}(\mathrm{iOPr})_{3}, 3 \mathrm{~A} \mathrm{MS}$ & 49.8 & 86.1 & 39 \\
\hline 2. & $\mathrm{CH}_{2} \mathrm{Cl}_{2}, \mathrm{VO}(i \mathrm{OPr})_{3}, 3 \AA \mathrm{MS}$ & 16.4 & 18.3 & 36 \\
\hline 3. & $\mathrm{PhMe}, \mathrm{VO}(\mathrm{iOPr})_{3}, 3 \AA \AA M S$ & 15.0 & 16.1 & 27 \\
\hline 4. & Acetone, $\mathrm{VO}(i \mathrm{OPr})_{3}$, no sieves & 27.6 & 42.0 & $>50$ \\
\hline 5. & Acetone, $\mathrm{VO}(\mathrm{acac})_{2}$, no sieves & 26.3 & 30.2 & 16 \\
\hline 6. & Acetone, $\mathrm{V}_{2} \mathrm{O}_{5}$, no sieves & $<5$ & -- & -- \\
\hline 7. & Acetone, $\mathrm{VOSO}_{4}$, no sieves & $<5$ & -- & -- \\
\hline
\end{tabular}

Representative Procedure for the Preparation of Methyl Mandelate Derivatives. $\mathrm{mL}$ ) was added bis(triphenylphosphine)iododioxorhenium(V) (0.998 g, $1.15 \mathrm{mmol})$. Trimethylsilylcyanide (4.0 mL, $30.0 \mathrm{mmol}$ ) was then added and the resulting purple suspension was heated to $60{ }^{\circ} \mathrm{C}$ overnight with stirring. After cooling to room temperature, silica gel was added to the reaction mixture to form a thick slurry and stirred for an additional $30 \mathrm{~min}$. The slurry was filtered over a pad of silica gel (ethyl acetate eluent, $300 \mathrm{~mL}$ ), and the filtrate was concentrated with a rotary evaporator. Column chromatography (silica gel, 4:1 Hex:EtOAc) afforded the cyanohydrin as a light yellow solid (4.40 g, 95\% yield). To a solution of the cyanohydrin (4.40 g, $21.9 \mathrm{mmol})$ in 25 $\mathrm{mL}$ of diethyl ether at $0{ }^{\circ} \mathrm{C}$ was added methanol $(1.33 \mathrm{~mL}, 32.8 \mathrm{mmol})$. The reaction mixture was saturated with hydrochloric acid by bubbling anhydrous $\mathrm{HCl}_{(\mathrm{g})}$ through the reaction mixture for $30 \mathrm{~min}$. The reaction mixture was then placed in a freezer $\left(-30^{\circ} \mathrm{C}\right)$ overnight. The resulting white precipitate was subsequently filtered and washed with cold diethyl ether. The white solid was transferred to a $100 \mathrm{~mL}$ round bottom flask and left under vacuum for 1 h. Water $(130 \mathrm{~mL})$ was then added and the resulting mixture was stirred overnight at ambient temperature. The heterogeneous mixture was filtered and washed with water to yield the $\alpha$-hydroxy ester as a white solid (3.99 g, $78 \%$ yield).

Characterization Data for Entry 2, Table 2. ${ }^{1} \mathrm{H}$ NMR $\left(400 \mathrm{MHz}, \mathrm{CDCl}_{3}\right) \delta 7.32(\mathrm{~m}, 2 \mathrm{H}), 6.89$
$(\mathrm{~m}, 2 \mathrm{H}), 5.13(\mathrm{~s}, 1 \mathrm{H}), 3.80(\mathrm{~s}, 3 \mathrm{H}), 3.75(\mathrm{~s}, 3 \mathrm{H}), 3.40(\mathrm{br} \mathrm{s}, 1 \mathrm{H}) ;{ }^{13} \mathrm{C} \mathrm{NMR}\left(100 \mathrm{MHz}_{\mathrm{NeO}} \mathrm{CDCl}\right)_{3} \delta$ 174.4, 159.8, 130.5, 127.9, 114.1, 72.5, 55.3, 53.0; Anal. Calc'd for $\mathrm{C}_{10} \mathrm{H}_{12} \mathrm{O}_{4}$ : C, 61.22; H, 6.16; Found: C, 61.05; H, 6.43. See Table S2 for chiral assay method. 


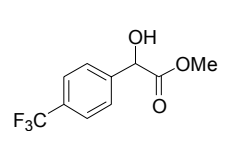

Characterization Data for Entry 3, Table 2. ${ }^{1} \mathrm{H}$ NMR $\left(400 \mathrm{MHz}, \mathrm{CDCl}_{3}\right) \delta 7.63(\mathrm{~m}, 2 \mathrm{H}), 7.57$ $(\mathrm{m}, 2 \mathrm{H}), 5.25(\mathrm{~d}, 1 \mathrm{H}, J=4.0 \mathrm{~Hz}), 3.78(\mathrm{~s}, 3 \mathrm{H}), 3.55(\mathrm{~d}, 1 \mathrm{H}, J=4.0 \mathrm{~Hz}) ;{ }^{13} \mathrm{C}$ NMR $\left(100 \mathrm{MHz}, \mathrm{CDCl}_{3}\right)$ $\delta$ 173.5, 142.0, 130.9, 130.6, 126.9, 125.5, 72.3, 53.4; Anal. Calc'd for $\mathrm{C}_{10} \mathrm{H}_{9} \mathrm{~F}_{3} \mathrm{O}_{3}$ : C, 51.29; $\mathrm{H}$, 3.87; Found: C, 51.10; H, 3.91. See Table S2 for chiral assay method.

OHOH

Preparation of Substrate for Entry 4, Table 2. To a $100 \mathrm{~mL}$ round bottom flask equipped with a added tiglaldehyde $(2.0 \mathrm{~g}, 24 \mathrm{mmol})$ as a solution in $50 \mathrm{~mL}$ of tetrahydrofuran. Trimethylsilylcyanide (4.8 $\mathrm{mL}, 36$ mmol) was then added and the resulting purple suspension was heated to $60{ }^{\circ} \mathrm{C}$ overnight with stirring. After cooling to room temperature, silica gel was added to the reaction mixture to form a thick slurry and stirred for an additional $30 \mathrm{~min}$. The slurry was filtered over a pad of silica gel (diethyl ether eluent, $300 \mathrm{~mL}$ ), and the filtrate was concentrated with a rotary evaporator. Column chromatography (silica gel, $3: 1 \rightarrow 2: 1 \mathrm{Hex}_{\mathrm{Et}} \mathrm{O}$ ) afforded the allylic cyanohydrin $^{5}(1.83 \mathrm{~g}, 69 \%$ yield). To a solution of the cyanohydrin $(1.83 \mathrm{~g}, 16.5 \mathrm{mmol})$ in $20 \mathrm{~mL}$ of diethyl ether at $0{ }^{\circ} \mathrm{C}$ was added benzyl alcohol $(2.67 \mathrm{~g}, 24.7 \mathrm{mmol})$. The reaction mixture was saturated with hydrochloric acid by bubbling anhydrous $\mathrm{HCl}_{(\mathrm{g})}$ through the reaction mixture for $45 \mathrm{~min}$. The reaction mixture was then placed in a freezer $\left(-30{ }^{\circ} \mathrm{C}\right)$ overnight. The resulting white precipitate was subsequently filtered and washed with cold diethyl ether. The white solid was transferred to a $100 \mathrm{~mL}$ round bottom flask and left under vacuum for 10 min. Distilled water $(50 \mathrm{~mL})$ was added and the resulting suspension was stirred for $2 \mathrm{~h}$ at room temperature. After extraction with diethyl ether, the $\alpha$-hydroxy benzyl ester was obtained as a clear oil (2.24 g, 61\% yield). ${ }^{1} \mathrm{H} \mathrm{NMR}(400 \mathrm{MHz}$, $\left.\mathrm{CDCl}_{3}\right) \delta 7.35(\mathrm{~m}, 5 \mathrm{H}), 5.65(\mathrm{~d}, 1 \mathrm{H}, J=6.8 \mathrm{~Hz}), 5.22(\mathrm{~s}, 2 \mathrm{H}), 4.55(\mathrm{~s}, 1 \mathrm{H}) ; 1.64(\mathrm{~d}, 3 \mathrm{H}, J=6.8 \mathrm{~Hz}), 1.43(\mathrm{~s}, 3 \mathrm{H})$. Chiral GC assay for the trifluoroacetyl derivative of the racemate (Chiraldex G-TA; $90{ }^{\circ} \mathrm{C}$ hold 0 min, then 10 ${ }^{\circ} \mathrm{C} / \mathrm{min}$ to $140{ }^{\circ} \mathrm{C}$ hold $10 \mathrm{~min} ; 2.0 \mathrm{~mL} / \mathrm{min}$ He carrier gas), $\mathrm{t}_{\mathrm{R}} 13.99 \mathrm{~min}, 14.32 \mathrm{~min}$.

Preparation of Substrate for Entry 7, Table 2. To a solution of $( \pm)$ - $\alpha$-hydroxy- $\gamma$-butyrolactone
in $50 \mathrm{~mL}$ of methanol was added $0.15 \mathrm{~mL}$ of concentrated hydrochloric acid. The resulting colorless solution was heated to reflux overnight. The volatile components of the reaction mixture were then removed with a rotary evaporator, and the residue was partitioned between brine and diethyl ether ( $3 \mathrm{x} 50 \mathrm{~mL})$. The combined organic components were washed with brine and dried $\left(\mathrm{Na}_{2} \mathrm{SO}_{4}\right)$. Column chromatography (silica gel, 10:1 EtOAc:Hex) gave the dihydroxy ester as a colorless oil. ${ }^{6}{ }^{1} \mathrm{H}$ NMR $\left(400 \mathrm{MHz}, \mathrm{CDCl}_{3}\right) \delta 4.44(\mathrm{~m}, 1 \mathrm{H}), 3.89-$ 3.77 (m, 2H), 3.78 (s, 3H), 2.66 (br s, 2H), 2.13-1.96 (m, 1H), 1.93-1.87 (m, 1H). The diol (2.25 g, $16.8 \mathrm{mmol})$ was dissolved in dimethylformamide $(15 \mathrm{~mL})$ at $0{ }^{\circ} \mathrm{C}$. To this clear solution was added imidazole $(1.32 \mathrm{~g}, 19.0 \mathrm{mmol})$, followed by $\mathrm{TBSCl}(2.66 \mathrm{~g}, 17.6 \mathrm{mmol})$ in two portions over $15 \mathrm{~min}$. The reaction mixture was warmed to room temperature overnight with stirring, and then diluted with water and extracted with EtOAc (3 x $100 \mathrm{~mL})$. The combined organic layers were washed with brine and dried $\left(\mathrm{MgSO}_{4}\right)$. Column chromatography (silica gel, 3:1

\footnotetext{
${ }^{4}$ (a) Cyanohydrin synthesis adapted from: Nolin, K.A.; Toste, F.D. Unpublished results. (b) For preparation of $(\mathrm{PPh})_{2} \mathrm{Re}(\mathrm{O})_{2} \mathrm{I}$, see: KennedySmith, J.J.; Nolin, K.A.; Gunterman, H.P.; Toste, F.D. J. Am. Chem. Soc. 2003, 125, 4056.

${ }^{5}$ Hayashi, M.; Miyamoto, Y.; Inoue, T.; Oguni, N. J. Org. Chem. 1993, 58, 1515.

${ }^{6}$ Hayashi, Y.; Yamaguchi, J.; Shoji, M. Tetrahedron 2002, 58, 9839.
} 
Hex: $\left.\mathrm{Et}_{2} \mathrm{O}\right)$ gave the siloxy ester as a clear, colorless oil. ${ }^{1} \mathrm{H} \mathrm{NMR}\left(400 \mathrm{MHz}, \mathrm{CDCl}_{3}\right) \delta 4.73(\mathrm{~m}, 1 \mathrm{H}), 3.82(\mathrm{~m}, 2 \mathrm{H})$, $3.78(\mathrm{~s}, 3 \mathrm{H}), 3.34(\mathrm{br} \mathrm{s}, 1 \mathrm{H}), 2.06(\mathrm{~m}, 1 \mathrm{H}), 1.87(\mathrm{~m}, 1 \mathrm{H}), 0.89(\mathrm{~s}, 9 \mathrm{H}), 0.06(\mathrm{~s}, 6 \mathrm{H})$. See Table $\mathrm{S} 2$ for chiral assay method. A sample of enantiopure siloxy ester for analytical comparison purposes was prepared from $(R)-(+)-\alpha-$ hydroxy- $\gamma$-butyrolactone by an identical procedure.

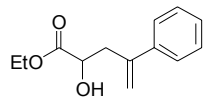

Preparation of Substrate for Entry 8, Table 2. A $50 \mathrm{wt} \%$ solution of ethyl glyoxylate in toluene $\left(10 \mathrm{~mL}, \sim 49 \mathrm{mmol}\right.$ ) was heated to reflux under argon for $4 \mathrm{~h}$. The solution was then cooled to $0{ }^{\circ} \mathrm{C}$ and $\alpha$-methylstyrene $(9.75 \mathrm{~mL}, 75 \mathrm{mmol})$ was added via syringe. Diethylaluminum chloride ( $25 \mathrm{~mL}, 1 \mathrm{M}$ in hexane) was added slowly. The reaction mixture was warmed to room temperature overnight with rapid stirring. A saturated aqueous solution of sodium sulfate was added slowly at $0{ }^{\circ} \mathrm{C}$ and the resulting white precipitate was filtered. The clear filtrate was partitioned between brine and EtOAc $(3 \times 150 \mathrm{~mL})$. The combined organic layers were washed with brine, dried $\left(\mathrm{MgSO}_{4}\right)$ and concentrated. Column chromatography (silica gel, 3:1 Hex:Et $\mathrm{t}_{2} \mathrm{O}$ ) afforded the homoallylic alcohol as a colorless oil (2.44 g, 55\% yield). See Table S2 for chiral assay method. Spectral data were consistent with reported literature values. ${ }^{7}$

Preparation of Substrate for Entry 9, Table 2. To a solution of benzoic acid ( $0.61 \mathrm{~g}, 5.0 \mathrm{mmol})$ in tetrahydrofuran $(5.0 \mathrm{~mL})$ was added via syringe benzaldehyde $(0.51 \mathrm{~mL}, 5.0 \mathrm{mmol})$ followed by tertbutylisocyanide $(0.59 \mathrm{~mL}, 5.0 \mathrm{mmol})$. The reaction mixture was heated to $50{ }^{\circ} \mathrm{C}$ with stirring for $16 \mathrm{~h}$. The resulting colorless mixture was cooled to room temperature, diluted with EtOAc, and transferred to a separatory funnel. The organic layer was washed with a saturated aqueous solution of $\mathrm{NaHCO}_{3}(3 \times 50 \mathrm{~mL})$, dried $\left(\mathrm{MgSO}_{4}\right)$, and concentrated to give a white solid, which was dissolved in methanol $(25 \mathrm{~mL})$. To the solution was added $\mathrm{NaOH}$ $(0.205 \mathrm{~g}, 5.1 \mathrm{mmol})$, and the resulting mixture was heated at reflux for $2 \mathrm{~h}$. The solvent was removed by rotary evaporation. The residue was partitioned between EtOAc and a saturated aqueous solution of $\mathrm{NaHCO}_{3}$ and the layers were separated. The aqueous layer was extracted with EtOAc $(3 \times 50 \mathrm{~mL})$ and the combine organic layers were washed with brine and dried $\left(\mathrm{Na}_{2} \mathrm{SO}_{4}\right)$. Column chromatography (silica gel, 2:1 Hex:EtOAc) gave the product as a white solid. ${ }^{1} \mathrm{H}$ NMR $\left(400 \mathrm{MHz}, \mathrm{CDCl}_{3}\right) \delta 7.34(\mathrm{~m}, 5 \mathrm{H}), 5.90(\mathrm{br} \mathrm{s}, 1 \mathrm{H}), 4.87(\mathrm{~s}, 1 \mathrm{H}), 3.85(\mathrm{br} \mathrm{s}, 1 \mathrm{H}), 1.31$ (s, $9 \mathrm{H}) ;{ }^{13} \mathrm{C}$ NMR $\left(100 \mathrm{MHz}, \mathrm{CDCl}_{3}\right) \delta 171.3,139.9,128.9,128.6,126.9,74.2,51.5$, 28.7. See Table S2 for chiral assay method.

General Procedure for the Oxidative Kinetic Resolution of Secondary Alcohols - Table 2. To a $100 \mathrm{~mL}$ round bottom flask equipped with magnetic stir bar was added ligand $1(110 \mathrm{mg}, 0.33 \mathrm{mmol}, 5.5 \mathrm{~mol} \%)$ followed by acetone $(15.0 \mathrm{~mL})$ at ambient temperature to form a yellow solution. $\operatorname{VO}(\mathrm{Oi} \operatorname{Pr})_{3}(70 \mu \mathrm{L}, 0.30 \mathrm{mmol}, 5 \mathrm{~mol} \%)$ was then added, and the resulting dark solution was stirred under an atmosphere of oxygen for $15 \mathrm{~min}$. The alcohol (6.00 mmol, 1.0 equiv) was then added via syringe as a solution in $15.0 \mathrm{~mL}$ of acetone with $50 \mathrm{mg}$ of an inert internal standard (hexamethylbenzene or durene). Aliquots of the reaction mixture were removed via syringe at intervals to monitor for percent conversion and enantiomeric excess. Each aliquot $(0.1 \mathrm{~mL})$ was filtered over a 3 -cm Pasteur pipette silica gel column (diethyl ether eluent), and the filtrate was analyzed by TLC, GC, and HPLC as necessary

\footnotetext{
${ }^{7}$ Evans, D.A.; Burgey, C.S.; Paras, N.A.; Vojkovsky, T.; Tregay, S.W. J. Am. Chem. Soc. 1998, 120, 5824.
} 
(see Table S2 for details). Upon completion of the reaction ( $\sim 50 \%$ conversion), silica gel was added to the reaction mixture to form a thick slurry, which was stirred for $30 \mathrm{~min}$. The slurry was then filtered over a pad of silica gel (diethyl ether eluent, $500 \mathrm{~mL}$ ). The filtrate was concentrated on a rotary evaporator and the resulting residue was purified by column chromatography on silica gel (see Table S3 for details).

Table S2. Methods for the Determination of Percent Conversion and Enantiomeric Excess.

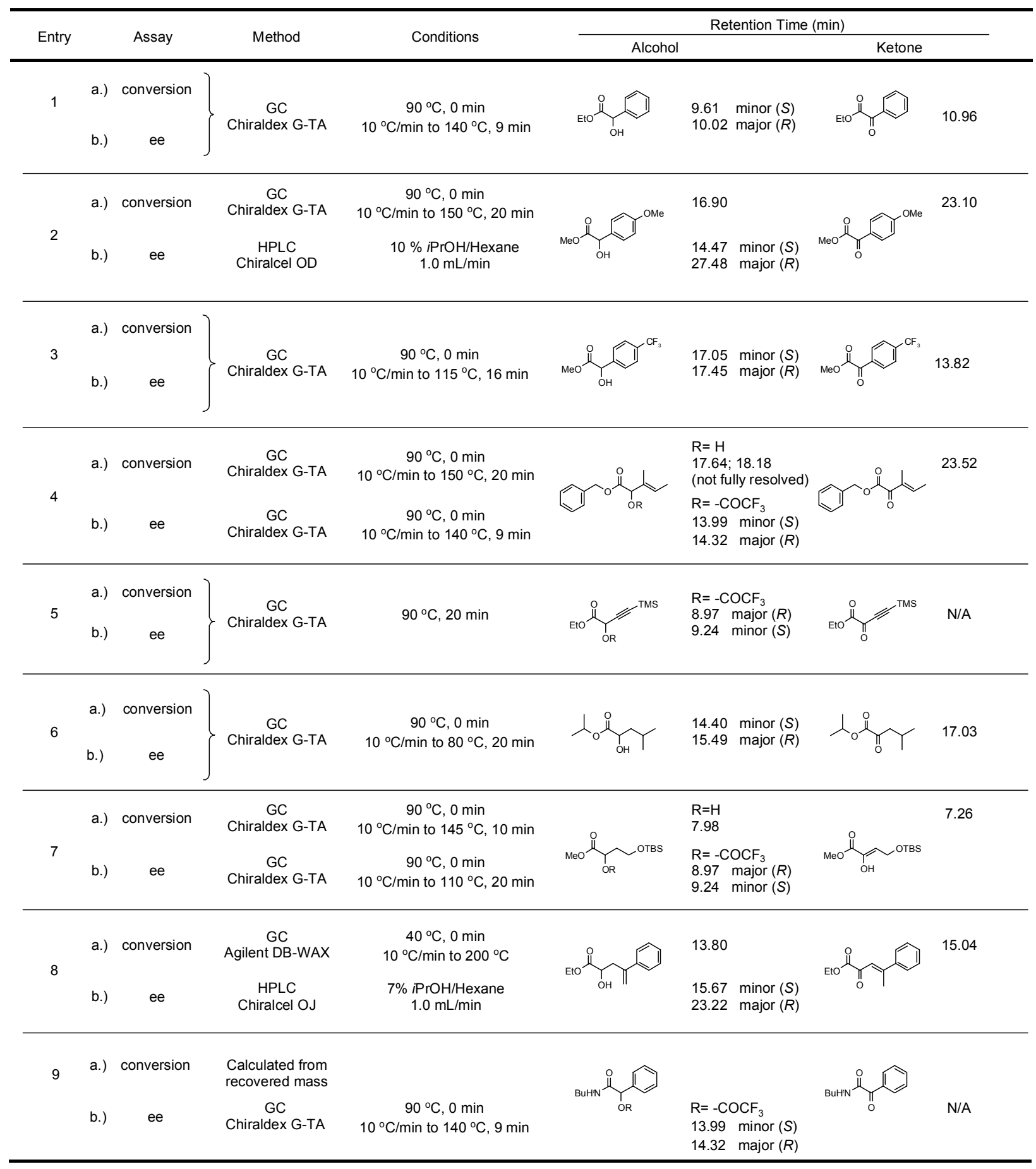


Table S3. Details of Preparative Scale Resolution Experiments.

\begin{tabular}{|c|c|c|c|c|c|c|c|c|c|c|}
\hline Entry & Amount & Time & Conversion & Chromatography & Alcohol & Mass & ee & s & Ketone & Mass \\
\hline 1. & $\begin{array}{c}1.08 \mathrm{~g} \\
(6.00 \mathrm{mmol})\end{array}$ & $10 \mathrm{~h}$ & $51 \%$ & $10: 1 \rightarrow 3: 1 \mathrm{Hex} \mathrm{Et}_{2} \mathrm{O}$ & & $\begin{array}{c}535 \mathrm{mg} \\
(49 \%)\end{array}$ & $99 \%$ & $>50$ & & $\begin{array}{c}478 \mathrm{mg} \\
(45 \%)\end{array}$ \\
\hline 2. & $\begin{array}{c}1.18 \mathrm{~g} \\
(6.00 \mathrm{mmol})\end{array}$ & $5.5 \mathrm{~h}$ & $62 \%$ & $4: 1 \rightarrow 1: 1 \mathrm{Hex} \mathrm{Et}_{2} \mathrm{O}$ & & $\begin{array}{c}448 \mathrm{mg} \\
(38 \%)\end{array}$ & $95 \%$ & 13 & & $\begin{array}{c}355 \mathrm{mg} \\
(31 \%)\end{array}$ \\
\hline 3. & $\begin{array}{c}1.41 \mathrm{~g} \\
(6.00 \mathrm{mmol})\end{array}$ & $4.0 \mathrm{~h}$ & $57 \%$ & $19: 1 \rightarrow 4: 1 \mathrm{Hex}:$ EtOAc & & $\begin{array}{c}495 \mathrm{mg} \\
(35 \%)\end{array}$ & $98 \%$ & 29 & & $\begin{array}{c}707 \mathrm{mg} \\
(51 \%)\end{array}$ \\
\hline 4. & $\begin{array}{c}1.32 \mathrm{~g} \\
(6.00 \mathrm{mmol})\end{array}$ & $16 \mathrm{~h}$ & $57 \%$ & $20: 1 \rightarrow 1: 1 \mathrm{Hex} \mathrm{Et}_{2} \mathrm{O}$ & & $\begin{array}{c}594 \mathrm{mg} \\
(45 \%)\end{array}$ & $92 \%$ & 18 & & $\begin{array}{c}585 \mathrm{mg} \\
(45 \%)\end{array}$ \\
\hline 5. & $\begin{array}{c}0.525 \mathrm{~g} \\
(2.62 \mathrm{mmol})\end{array}$ & $5.0 \mathrm{~h}$ & $47 \%$ & $5: 1 \rightarrow 3: 1 \mathrm{Hex} \mathrm{Et}_{2} \mathrm{O}$ & & $\begin{array}{c}280 \mathrm{mg} \\
(53 \%)\end{array}$ & $50 \%$ & 6 & & $\begin{array}{c}165 \mathrm{mg} \\
(32 \%)\end{array}$ \\
\hline 6. & $\begin{array}{c}1.05 \mathrm{~g} \\
(6.00 \mathrm{mmol})\end{array}$ & $90 \mathrm{~h}$ & $55 \%$ & $25: 1 \rightarrow 3: 1 \mathrm{Hex} \mathrm{Et}_{2} \mathrm{O}$ & & $\begin{array}{c}394 \mathrm{mg} \\
(37 \%)\end{array}$ & $98 \%$ & 30 & & $\begin{array}{c}498 \mathrm{mg} \\
(49 \%)\end{array}$ \\
\hline 7. & $\begin{array}{c}1.49 \mathrm{~g} \\
(6.00 \mathrm{mmol})\end{array}$ & $144 \mathrm{~h}$ & $51 \%$ & $10: 1 \rightarrow 3: 1 \mathrm{Hex} \mathrm{Et}_{2} \mathrm{O}$ & & $\begin{array}{c}716 \mathrm{mg} \\
(48 \%)\end{array}$ & $90 \%$ & 42 & & $\begin{array}{c}694 \mathrm{mg} \\
(47 \%)\end{array}$ \\
\hline 8. & $\begin{array}{c}1.32 \mathrm{~g} \\
(6.00 \mathrm{mmol})\end{array}$ & $72 \mathrm{~h}$ & $48 \%$ & $8: 1 \rightarrow 3: 1 \mathrm{Hex} \mathrm{Et}_{2} \mathrm{O}$ & & $\begin{array}{c}629 \mathrm{mg} \\
(48 \%)\end{array}$ & $90 \%$ & 34 & & $\begin{array}{c}525 \mathrm{mg} \\
(40 \%)\end{array}$ \\
\hline $9 .^{a}$ & $\begin{array}{c}0.13 \mathrm{~g} \\
(0.63 \mathrm{mmol})\end{array}$ & $16 \mathrm{~h}$ & $52 \%$ & $4: 1 \rightarrow 2: 1 \mathrm{Hex} \mathrm{Et}_{2} \mathrm{O}$ & & $\begin{array}{l}63 \mathrm{mg} \\
(48 \%)\end{array}$ & $72 \%$ & 12 & & $\begin{array}{l}63 \mathrm{mg} \\
(49 \%)\end{array}$ \\
\hline
\end{tabular}

${ }^{a-}$ Reaction conducted at $40{ }^{\circ} \mathrm{C}$. 

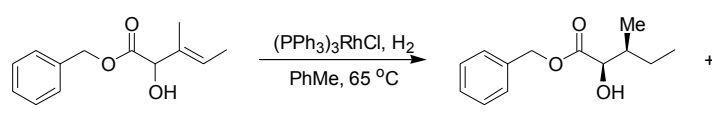

$( \pm)-2$

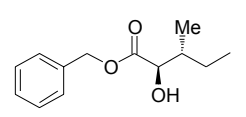

$( \pm)-4$
Preparation of syn- and anti-benzyl-2hydroxy-3-methylpentanoate - ( \pm -2 and

( \pm )-4. To a solution of the allylic alcohol

$(860 \mathrm{mg}, 3.9 \mathrm{mmol})$ in dry toluene $(16 \mathrm{~mL})$ under argon was added $\left(\mathrm{PPh}_{3}\right)_{3} \mathrm{RhCl}(360 \mathrm{mg}, 0.39 \mathrm{mmol})$. The reaction flask was vacuum evacuated and filled with $\mathrm{H}_{2}$ three times. The reaction mixture was warmed to $65{ }^{\circ} \mathrm{C}$ and the temperature maintained with stirring overnight. The reaction mixture was concentrated with a rotary evaporator, and the residue was chromatographed (silica gel, 5:1 Hex: $\mathrm{Et}_{2} \mathrm{O}$ ) to give diastereomer ( \pm )-2 followed by diastereomer $( \pm)-4$. Repeated column chromatography was necessary to obtain pure samples of the individual diastereomers.

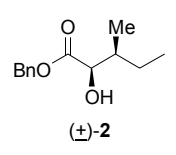

Characterization Data for $( \pm)-2 .{ }^{1} \mathrm{H} \mathrm{NMR}\left(400 \mathrm{MHz}, \mathrm{CDCl}_{3}\right) \delta 7.37(\mathrm{~m}, 5 \mathrm{H}), 5.22(\mathrm{~m}, 2 \mathrm{H}), 4.23$ (app s, 1H), 2.79 (br s, 1H), $1.84(\mathrm{~m}, 1 \mathrm{H}), 1.52$ (m, 1H), $1.29(\mathrm{~m}, 1 \mathrm{H}), 0.96(\mathrm{t}, 3 \mathrm{H}, J=7.2 \mathrm{~Hz}), 0.78$ (d, $3 \mathrm{H}, J=7.2 \mathrm{~Hz}) ;{ }^{13} \mathrm{C}$ NMR $\left(100 \mathrm{MHz}, \mathrm{CDCl}_{3}\right) \delta 175.3,135.2,128.6,128.5,128.4,73.0,67.3,38.5,25.9$, 13.1, 11.8; Chiral GC assay for racemic sample (Chiraldex G-TA; $90{ }^{\circ} \mathrm{C}$ hold 0 min, then $10{ }^{\circ} \mathrm{C} / \mathrm{min}$ to $150{ }^{\circ} \mathrm{C}$ hold $20 \mathrm{~min} ; 2.0 \mathrm{~mL} / \mathrm{min}$ He carrier gas), $\mathrm{t}_{\mathrm{R}} 14.56 \mathrm{~min}, 14.77 \mathrm{~min}$.

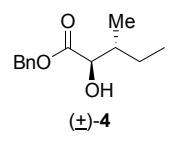

Characterization Data for $( \pm)-4 .{ }^{1} \mathrm{H}$ NMR $\left(400 \mathrm{MHz}, \mathrm{CDCl}_{3}\right) \delta 7.34(\mathrm{~m}, 5 \mathrm{H}), 5.21(\mathrm{~m}, 2 \mathrm{H}), 4.12(\mathrm{~d}$, $1 \mathrm{H}, J=4.8 \mathrm{~Hz}), 2.78($ br s, $1 \mathrm{H}), 1.83(\mathrm{~m}, 1 \mathrm{H}), 1.46-1.17(\mathrm{~m}, 2 \mathrm{H}), 0.97(\mathrm{~d}, 3 \mathrm{H}, J=7.2 \mathrm{~Hz}), 0.86(\mathrm{t}, 3 \mathrm{H}$, $J=7.2 \mathrm{~Hz}) ;{ }^{13} \mathrm{C}$ NMR $\left(100 \mathrm{MHz}, \mathrm{CDCl}_{3}\right) \delta 175.2,135.5,128.9,128.8,128.7,75.1,67.5,39.4,23.9$, 15.7, 12.0; Chiral GC assay for racemic sample (Chiraldex G-TA; $90{ }^{\circ} \mathrm{C}$ hold 0 min, then $10{ }^{\circ} \mathrm{C} / \mathrm{min}$ to $145^{\circ} \mathrm{C}$ hold $20 \mathrm{~min} ; 2.0 \mathrm{~mL} / \mathrm{min}$ He carrier gas), $\mathrm{t}_{\mathrm{R}} 16.58 \mathrm{~min}, 16.83 \mathrm{~min}$.

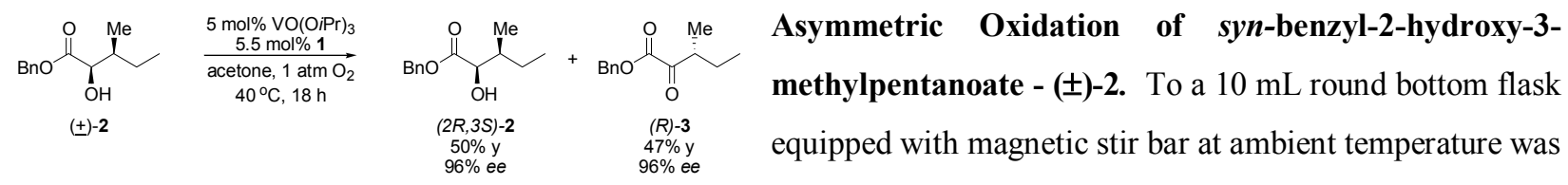
added ligand 1 (11.6 mg, $0.035 \mathrm{mmol}, 5.5 \mathrm{~mol} \%)$ followed by acetone $(1.6 \mathrm{~mL})$ to form a yellow solution. $\mathrm{VO}(\mathrm{O} i \operatorname{Pr})_{3}(7.6 \mu \mathrm{L}, 0.032 \mathrm{mmol}, 5 \mathrm{~mol} \%)$ was then added, and the resulting dark solution was stirred under an atmosphere of oxygen for $10 \mathrm{~min}$. The alcohol $(140 \mathrm{mg}, 0.63 \mathrm{mmol})$ was then added via syringe as a solution in 1.6 $\mathrm{mL}$ of acetone. The reaction mixture was maintained at $40{ }^{\circ} \mathrm{C}$ for $18 \mathrm{~h}$ with stirring. The solvent was then removed with a rotary evaporator and the residue was purified by column chromatography (silica gel, 6:1 $\rightarrow 3: 1 \mathrm{Hex}_{\mathrm{Et}} \mathrm{O}$ ) to give $(R)-3$ (65 mg, $47 \%$ yield) followed by $(2 R, 3 S)-2(70 \mathrm{mg}, 50 \%$ yield). Enantiomeric excess of 2 was determined by chiral GC (Chiraldex G-TA; $90{ }^{\circ} \mathrm{C}$ hold $0 \mathrm{~min}$, then $10{ }^{\circ} \mathrm{C} / \mathrm{min}$ to $150{ }^{\circ} \mathrm{C}$ hold $20 \mathrm{~min} ; 2.0 \mathrm{~mL} / \mathrm{min}$ He carrier gas), $t_{\mathrm{R}} 14.56 \mathrm{~min}$ (minor, $(2 S, 3 R)$ ), $14.77 \mathrm{~min}$ (major, $(2 R, 3 S)$ ). Enantiomeric excess of 3 was determined by chiral HPLC (Chiralcel OJ column, 99:1 hexanes:isopropanol, $1 \mathrm{~mL} / \mathrm{min}$ ) $\mathrm{t}_{\mathrm{R}} 22.46 \mathrm{~min}(\mathrm{minor},(S)$ ), 25.93 min (major, $(R)$ ); Absolute stereochemistry of compound $(R)-3$ was assigned by comparison of HPLC 
retention times with compound $(S)-\mathbf{3}$, see below for details. Absolute stereochemistry of compound $(2 R, 3 S)-\mathbf{2}$ was assigned as a consequence of the assignment of $(R)-3$.

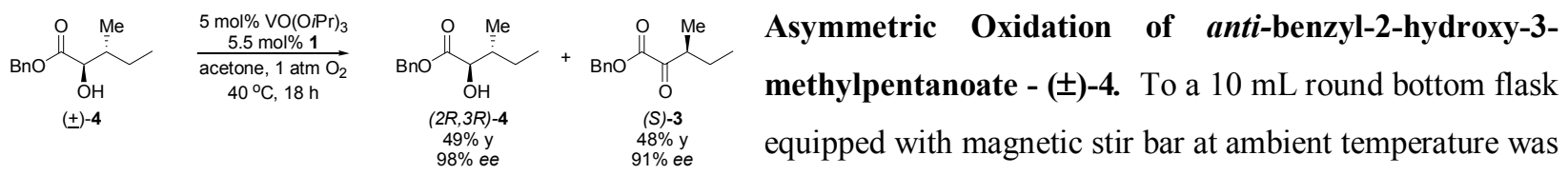
added ligand $1(11.6 \mathrm{mg}, 0.035 \mathrm{mmol}, 5.5 \mathrm{~mol} \%)$ followed by acetone $(1.6 \mathrm{~mL})$ to form a yellow solution. $\operatorname{VO}(\mathrm{OiPr})_{3}(7.6 \mu \mathrm{L}, 0.032 \mathrm{mmol}, 5 \mathrm{~mol} \%)$ was then added, and the resulting dark solution was stirred under an atmosphere of oxygen for $10 \mathrm{~min}$. The alcohol $(140 \mathrm{mg}, 0.63 \mathrm{mmol})$ was then added via syringe as a solution in 1.6 $\mathrm{mL}$ of acetone. The reaction mixture was maintained at $40{ }^{\circ} \mathrm{C}$ for $18 \mathrm{~h}$ with stirring. The solvent was then removed by rotary evaporation and the residue was purified by column chromatography (silica gel, $6: 1 \rightarrow 3: 1 \mathrm{Hex}_{\mathrm{E}} \mathrm{Et}_{2} \mathrm{O}$ ) to give (S)-3 (66 mg, 48\% yield) followed by (2R,3R)-4 (69 mg, 49\% yield). Enantiomeric excess of 4 was determined by chiral GC (Chiraldex G-TA; $90{ }^{\circ} \mathrm{C}$ hold $0 \mathrm{~min}$, then $10^{\circ} \mathrm{C} / \mathrm{min}$ to $145^{\circ} \mathrm{C}$ hold $20 \mathrm{~min} ; 2.0 \mathrm{~mL} / \mathrm{min} \mathrm{He}$ carrier gas), $\mathrm{t}_{\mathrm{R}} 16.58 \mathrm{~min}$ (minor, $(2 S, 3 S)$ ), 16.83 min (major, $(2 R, 3 R)$ ). Enantiomeric excess of $\mathbf{3}$ was determined by chiral HPLC (Chiralcel OJ column, 99:1 hexanes:isopropanol, $1 \mathrm{~mL} / \mathrm{min}$ ) $\mathrm{t}_{\mathrm{R}} 22.53 \mathrm{~min}$ (major, $(S)$ ), 25.98 min (minor, $(R))$. Absolute stereochemistry of compound 4 was assigned by comparison of optical rotation data to literature value: $[\alpha]_{\mathrm{D}}=+2.7\left(\mathrm{c} 2.0, \mathrm{CHCl}_{3}\right),\left(\right.$ lit: $\left.^{8}[\alpha]_{\mathrm{D}}=-4.1\left(\mathrm{c} 2.0, \mathrm{CHCl}_{3}\right)\right)$. Absolute stereochemistry of compound 3 was assigned as a consequence of the assignment of compound 4 .

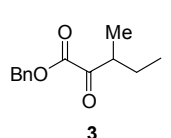

Characterization Data for 3. ${ }^{1} \mathrm{H} \mathrm{NMR}\left(400 \mathrm{MHz}, \mathrm{CDCl}_{3}\right) \delta 7.37(\mathrm{~m}, 5 \mathrm{H}), 5.28(\mathrm{~s}, 2 \mathrm{H}), 3.13(\mathrm{~m}, 1 \mathrm{H})$, $1.73(\mathrm{~m}, 1 \mathrm{H}), 1.42(\mathrm{~m}, 1 \mathrm{H}), 1.12(\mathrm{~d}, 3 \mathrm{H}, J=7.2 \mathrm{~Hz}), 0.90(\mathrm{t}, 3 \mathrm{H}, J=7.2 \mathrm{~Hz}) ;{ }^{13} \mathrm{C}$ NMR $(100 \mathrm{MHz}$, $\left.\mathrm{CDCl}_{3}\right) \delta 197.8,161.8,134.6,128.7,128.6,128.5,67.7,43.7,24.8,14.5,12.3$; Chiral HPLC assay for racemic sample (Chiralcel OJ column, 99:1 hexanes:isopropanol, $1 \mathrm{~mL} / \mathrm{min}$ ) $t_{\mathrm{R}} 22.49 \mathrm{~min}, 25.95 \mathrm{~min}$.

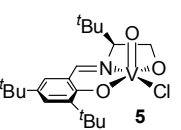

Preparation of Chlorovanadate 5. To a solution of $\mathrm{VOCl}_{3}(44 \mu \mathrm{L}, 0.465 \mathrm{mmol})$ in dry THF (15 $\mathrm{mL})$ at room temperature was slowly added ligand $\mathbf{1}$ as a solution in THF $(5 \mathrm{~mL})$. The dark reaction mixture was stirred at room temperature for $30 \mathrm{~min}$ and then concentrated with a rotary evaporator to a black residue. Hexanes $(10 \mathrm{~mL})$ was added and the mixture was left to stand for $30 \mathrm{~min}$. Filtration of the mixture afforded chlorovanadate 5 (167 $\mathrm{mg}, 82 \%$ yield) as a black solid. Spectral data were consistent with reported literature values. ${ }^{9}{ }^{51} \mathrm{~V}$ NMR $\left(131.53 \mathrm{MHz}, \mathrm{CD}_{2} \mathrm{Cl}_{2}\right) \delta-432 \mathrm{ppm}$.

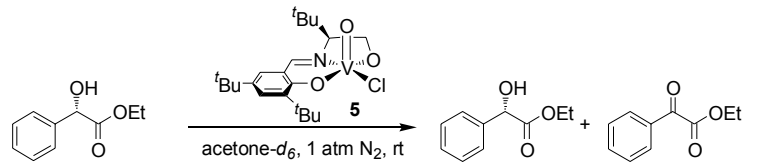

Stoichiometric Reaction of $(S)$-Ethyl Mandelate and Chlorovanadate 5. A $5 \mathrm{~mL}$ portion of acetone- $d_{6}$ was degassed via successive freeze-pump-thaw cycles in a $10 \mathrm{~mL}$ Schlenk flask and used in the following procedure. The following manipulations were conducted in an inert

\footnotetext{
${ }^{8}$ Shin, I.; Lee, M.-r.; Lee, J.; Jung, M.; Lee, W.; Yoon, J. J. Org. Chem. 2000, 65, 7667.

${ }^{9}$ Blum, S.A.; Bergman, R.G.; Ellman, J.A. J. Org. Chem. 2003, 68, 150.
} 
atmosphere $\left(\mathrm{N}_{2}\right)$ glove box using oven-dried glassware. Spectra (NMR, EPR) were recorded in solution using airtight spectroscopy tubes. Chlorovanadate $5(130 \mathrm{mg}, 0.30 \mathrm{mmol})$ was dissolved in $3.0 \mathrm{~mL}$ of acetone- $d_{6}$, a ${ }^{51} \mathrm{~V}$ NMR spectrum of which shows a signal at $\delta-438 \mathrm{ppm}$. (S)-(+)-Ethyl mandelate $(54 \mathrm{mg}, 0.30 \mathrm{mmol})$ was added as a solid and the dark reaction mixture was stirred at room temperature for $18 \mathrm{~h}$, over the course of which the reaction mixture became green. An aliquot of the green reaction mixture was analyzed by NMR and EPR spectroscopy. A ${ }^{1} \mathrm{H}$ NMR spectrum indicated partial consumption of ethyl mandelate. ${ }^{51} \mathrm{~V}$ NMR of the aliquot showed no signals in the range +2500 to $-2000 \mathrm{ppm}$. An X-band EPR spectrum exhibited an eight line signal ( $\mathrm{g}=1.97$, Figure $\mathrm{S} 2$ ). The green reaction mixture was subsequently exposed to an atmosphere of oxygen and stirred at room temperature for an additional $12 \mathrm{~h}$, over the course of which the reaction mixture became dark in color. Analysis of an aliquot of the mixture by ${ }^{1} \mathrm{H}$ NMR indicated complete consumption of ethyl mandelate and ${ }^{51} \mathrm{~V}$ NMR spectra show regeneration of a signal at $\delta-438 \mathrm{ppm}$.

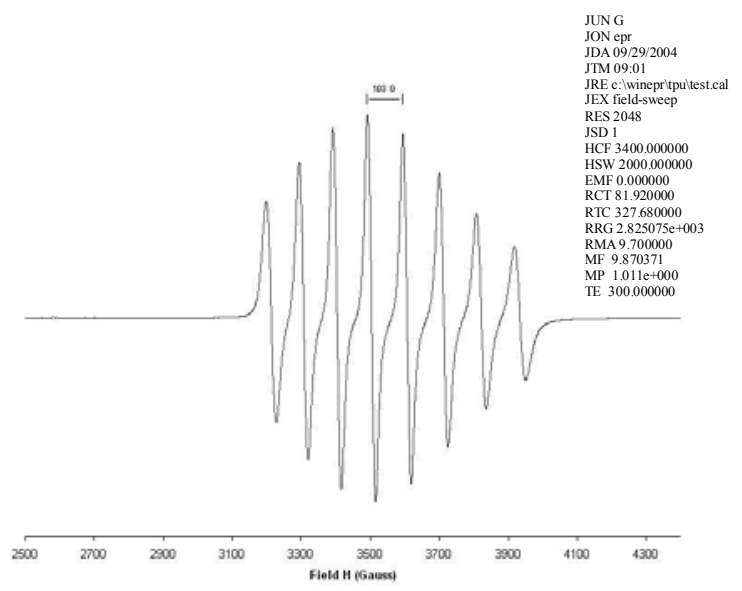

Figure S2. EPR spectrum of Vanadium Intermediate After Single Turnover.

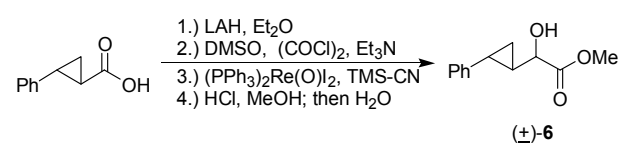

Preparation of Cyclopropane ( \pm )-6. To a suspension of lithium aluminum hydride $(0.29 \mathrm{~g}, 7.7 \mathrm{mmol})$ in $\operatorname{dry} \mathrm{Et}_{2} \mathrm{O}(15 \mathrm{~mL})$ at $0{ }^{\circ} \mathrm{C}$ under nitrogen was added dropwise trans-2-phenylcyclopropane-1carboxylic acid $(1.0 \mathrm{~g}, 6.17 \mathrm{mmol})$ as a solution in $10 \mathrm{~mL}$ of dry $\mathrm{Et}_{2} \mathrm{O}$. The reaction mixture was stirred at $0{ }^{\circ} \mathrm{C}$ for $3 \mathrm{~h}$, and then quenched by slow addition of a saturated solution of Rochelle's salt. The mixture was extracted with ether $(3 \times 50 \mathrm{~mL})$ and the combined organic layers washed with brine, concentrated, and dried $\left(\mathrm{MgSO}_{4}\right)$ to give the cyclopropyl alcohol as a colorless oil. The alcohol in $\mathrm{CH}_{2} \mathrm{Cl}_{2}(15 \mathrm{~mL})$ was added dropwise to a premixed $(1.5 \mathrm{~h},-78$ $\left.{ }^{\circ} \mathrm{C}\right)$ solution of oxalyl chloride $(0.81 \mathrm{~mL}, 9.26 \mathrm{mmol})$ and dimethylsulfoxide $(1.75 \mathrm{~mL}, 24.7 \mathrm{mmol})$ in $\mathrm{CH}_{2} \mathrm{Cl}_{2}$ at -78 ${ }^{\circ} \mathrm{C}$, and then stirred for $1 \mathrm{~h}$. Triethylamine $(8.4 \mathrm{~mL}, 60.17 \mathrm{mmol})$ was then added dropwise at $-78{ }^{\circ} \mathrm{C}$, and the reaction mixture was subsequently warmed to room temperature with stirring overnight. The reaction mixture was quenched by addition of an aqueous solution of $0.1 \mathrm{M} \mathrm{HCl}$, and extracted with $\mathrm{CH}_{2} \mathrm{Cl}_{2}(3 \times 50 \mathrm{~mL})$. The combined organic layers were washed with an aqueous solution of $0.1 \mathrm{M} \mathrm{HCl}$ and brine and then concentrated and dried 
$\left(\mathrm{MgSO}_{4}\right)$. Column chromatography (silica gel, 10:1 $\left.\rightarrow 5: 1 \mathrm{Hex}_{\mathrm{Et}} \mathrm{O}\right)$ gave the cyclopropyl aldehyde as a colorless oil, which solidified to a white solid upon refrigeration. The aldehyde was dissolved in $12 \mathrm{~mL}$ of tetrahydrofuran, to which was added bis(triphenylphosphine)iododioxorhenium(V) $(260 \mathrm{mg}, \quad 0.30 \mathrm{mmol})$ followed by trimethylsilylcyanide $(1.2 \mathrm{~mL}, 9.0 \mathrm{mmol})$. The purple reaction mixture was heated to $60^{\circ} \mathrm{C}$ for $3 \mathrm{~h}$, then cooled to room temperature. Silica gel was added to the reaction mixture to form a thick slurry and stirred for an additional 30 min. The slurry was filtered over a pad of silica gel (diethyl ether eluent, $100 \mathrm{~mL}$ ), and the filtrate concentrated with a rotary evaporator. Column chromatography (silica gel, 10:1 $\rightarrow 1: 1 \quad \mathrm{Hex}_{\mathrm{Et}} \mathrm{O}$ ) afforded the cyclopropyl cyanohydrin (3.5:1 $d r$, NMR) as a light yellow oil. The following resonance were observed for the mixture of diastereomers: ${ }^{1} \mathrm{H}$ NMR $\left(400 \mathrm{MHz}, \mathrm{CDCl}_{3}\right) \delta 7.29(\mathrm{~m}, 2 \mathrm{H}), 7.21(\mathrm{~m}, 1 \mathrm{H}), 7.11(\mathrm{~m}, 2 \mathrm{H}), 4.50(\mathrm{~d}, 1 \mathrm{H}, J=6.4 \mathrm{~Hz}$, minor diastereomer), $4.42(\mathrm{~d}, 1 \mathrm{H}, J=6.4 \mathrm{~Hz}$, major diastereomer), $2.15(\mathrm{~m}, 1 \mathrm{H}), 1.67(\mathrm{~m}, 1 \mathrm{H}), 1.25-1.13(\mathrm{~m}, 2 \mathrm{H})$. The cyanohydrin was dissolved in $5 \mathrm{~mL}$ of methanol and cooled to $0{ }^{\circ} \mathrm{C}$. The solution was saturated with hydrochloric acid by bubbling anhydrous $\mathrm{HCl}$ through the reaction mixture for $30 \mathrm{~min}$. The reaction mixture was placed in a freezer overnight $\left(-30^{\circ} \mathrm{C}\right)$. The volatile components were removed by rotary evaporation and the yellow residue was stirred with distilled water at room temperature for $30 \mathrm{~min}$. The aqueous mixture was extracted with diethyl ether $(3 \times 30 \mathrm{~mL})$, and the combined organic layers were washed with a saturated aqueous solution of $\mathrm{NaHCO}_{3}$ and brine, and then dried $\left(\mathrm{Na}_{2} \mathrm{SO}_{4}\right)$. Column chromatography (silica gel, 2:1 Hex:Et $\left.2 \mathrm{O}\right)$ gave cyclopropyl methyl ester, a light yellow oil, as a 1:1 mixture of diastereomers ( $325 \mathrm{mg}, 26 \%$ over 4 steps). See below for spectral data.

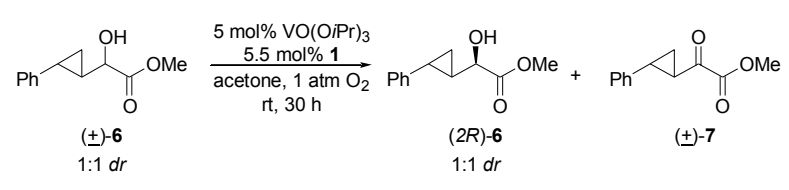

Asymmetric Oxidation of Cyclopropane ( \pm )-6. To a 2dram vial equipped with a magnetic stir bar was added ligand $1(8.4 \mathrm{mg}, 0.025 \mathrm{mmol})$ followed by $0.6 \mathrm{~mL}$ of acetone. $\operatorname{VO}(\mathrm{O} i \mathrm{Pr})_{3}(4.7 \mu \mathrm{L}, 0.020 \mathrm{mmol})$ was added via syringe and the dark mixture was stirred under oxygen for $10 \mathrm{~min}$. Cyclopropane $( \pm)-6$ (50 mg, $0.25 \mathrm{mmol})$ was added as a solution in $0.6 \mathrm{~mL}$ of acetone. The reaction mixture was stirred under oxygen at room temperature for 30 h. An aliquot $(0.1 \mathrm{~mL})$ of the crude reaction mixture was removed via syringe and filtered over a 3-cm Pasteur pipette column of silica gel (diethyl ether eluent). The filtrate was treated with trifluoroacetic anhydride and analyzed by chiral GC. The remaining crude reaction mixture was concentrated by rotary evaporation and analyzed by ${ }^{1} \mathrm{H}$ NMR spectroscopy. The only signals other than catalyst observed in the ${ }^{1} \mathrm{H}$ NMR spectrum were verified to belong to compounds 6 and 7 by chromatographic isolation (silica gel, 5:1 $\rightarrow 2: 1 \mathrm{Hex}_{\mathrm{Et}} \mathrm{O}$ ).

Characterization Data for 6. The following resonances were observed for the 1:1 mixture of $\overbrace{6}^{\mathrm{OH}} \mathrm{OMe}$ diastereomers of 6: ${ }^{1} \mathrm{H}$ NMR (400 MHz, $\left.\mathrm{CDCl}_{3}\right) \delta$ 7.34-7.24 (m, 4H), 7.19-7.15 (m, 2H), 7.10-7.07 (m, 4H), 4.10 (d, 1H, $J=6.0 \mathrm{~Hz}), 4.03(\mathrm{~d}, 1 \mathrm{H}, J=6.0 \mathrm{~Hz}), 3.84$ (s, 3H), $3.82(\mathrm{~s}, 3 \mathrm{H}), 2.14(\mathrm{~m}, 1 \mathrm{H}), 2.04$ (m, 1H), $1.45(\mathrm{~m}, 2 \mathrm{H}), 1.22(\mathrm{~m}, 1 \mathrm{H}), 1.12(1 \mathrm{H}), 0.96(\mathrm{~m}, 2 \mathrm{H}) ;{ }^{13} \mathrm{C}$ NMR $\left(100 \mathrm{MHz}, \mathrm{CDCl}_{3}\right) \delta 175.1,175.0,141.8$ (2), 128.3 (2), 126.1, 126.0, 125.8 (2), 71.3, 70.8, 52.8, 52.7, 25.6 (2), 19.5 (2), 12.0, 11.3; Chiral GC assay of the trifluoroacetyl derivative of the racemate (Chiraldex G-TA, $90{ }^{\circ} \mathrm{C}$ hold $0 \mathrm{~min}$, then $10^{\circ} \mathrm{C} / \mathrm{min}$ to $130{ }^{\circ} \mathrm{C}$ hold 30 
$\min ; 2.0 \mathrm{~mL} / \mathrm{min}$ He carrier gas), $\mathrm{t}_{\mathrm{R}}$ diastereomer A: $16.93 \mathrm{~min}$ (major), $17.22 \mathrm{~min}$ (minor); $\mathrm{t}_{\mathrm{R}}$ diastereomer B: 18.33 $\min$ (major), $18.73 \mathrm{~min}$ (minor).

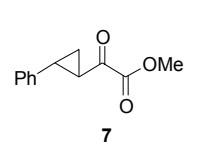

Characterization Data for 7. ${ }^{1} \mathrm{H}$ NMR $\left(400 \mathrm{MHz}, \mathrm{CDCl}_{3}\right) \delta$ 7.32-7.22 (m, 3H), $7.13(\mathrm{~m}, 2 \mathrm{H}), 3.89$ (s, 3H), $3.04(\mathrm{~m}, 1 \mathrm{H}), 2.72(\mathrm{~m}, 1 \mathrm{H}), 1.88(\mathrm{~m}, 1 \mathrm{H}), 1.66(\mathrm{~m}, 1 \mathrm{H}) ;{ }^{13} \mathrm{C} \mathrm{NMR}\left(100 \mathrm{MHz}, \mathrm{CDCl}_{3}\right) \delta$ $191.8,161.2,139.1,128.6,127.0,126.2,53.11,32.7,29.6,21.6$; Chiral GC assay for the racemic sample (Chiraldex G-TA, $90{ }^{\circ} \mathrm{C}$ hold $0 \mathrm{~min}$, then $10^{\circ} \mathrm{C} / \mathrm{min}$ to $130^{\circ} \mathrm{C}$ hold $30 \mathrm{~min} ; 2.0 \mathrm{~mL} / \mathrm{min} \mathrm{He}$ carrier gas), $\mathrm{t}_{\mathrm{R}}$ $38.35 \mathrm{~min}, 40.03 \mathrm{~min}$. 


\section{Chromatogram - Table 2, Entry 1 (racemic)}

Data File D: \HPCHEM \1\DATA \ALBX \JUN12005.D
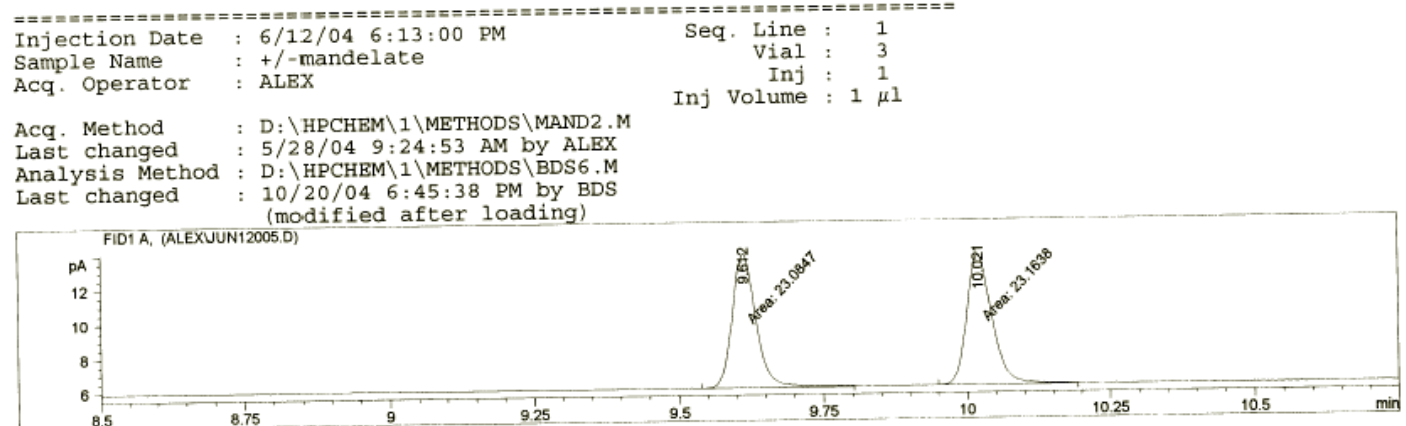

\begin{tabular}{|c|c|c|}
\hline Sorted By & : & Signal \\
\hline Multiplier & : & 1.0000 \\
\hline Dilution & : & 1.000 \\
\hline
\end{tabular}

Signal 1: FID1 A,

\begin{tabular}{|c|c|c|c|c|c|c|}
\hline $\begin{array}{c}\text { Peak } \\
\#\end{array}$ & $\begin{array}{l}\text { RetTime } \\
\text { [min] }\end{array}$ & Type & $\begin{array}{c}\text { Width } \\
\text { [min] }\end{array}$ & $\begin{array}{r}\text { Area } \\
{\left[\mathrm{pA}^{*} \mathrm{~s}\right]}\end{array}$ & $\begin{array}{l}\text { Height } \\
{[\mathrm{pA}]}\end{array}$ & $\begin{array}{c}\text { Area } \\
\frac{\circ}{8}\end{array}$ \\
\hline$\frac{1}{2}$ & $\begin{array}{r}9.612 \\
10.021\end{array}$ & $\begin{array}{l}\text { MM } \\
\text { MM }\end{array}$ & $\begin{array}{l}0.0491 \\
0.0503\end{array}$ & $\begin{array}{l}23.08471 \\
23.16382\end{array}$ & $\begin{array}{r}7.84093 \\
7.66774\end{array}$ & $\begin{array}{l}49.91447 \\
50.08553\end{array}$ \\
\hline & & & & 46.24853 & 15.50867 & \\
\hline
\end{tabular}

Totals :

$46.24853 \quad 15.50867$

\section{Chromatogram - Table 2, Entry 1 (resolved)}

Data File D: \HPCHEM \1\DATA \ALEX \UUL15006.D

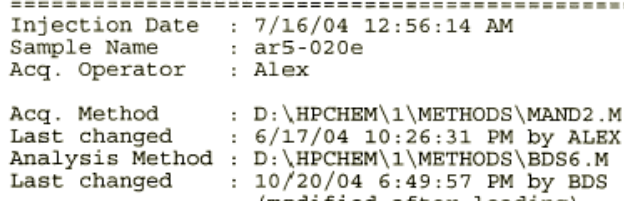


Chromatogram - Table 2, Entry 2 (racemic)

\begin{tabular}{|cc|}
\hline Sample ID: & OMe mandalate \\
Filename: & C $: \backslash$ EzStart $\backslash$ Projects $\backslash$ Default $\backslash$ Data $\backslash$ Christine $\backslash 8-23-2004$ \\
$11-56-51$ & AMCMM_OD9010IP. met.dat \\
C: $\backslash$ EZStart $\backslash$ Projects $\backslash$ Default $\backslash$ Method $\backslash$ Christine $\backslash$ CMM_oD9010IP.met \\
Injection volume: & $10 \mathrm{uL}$ \\
\hline
\end{tabular}

Description: \{Data Description
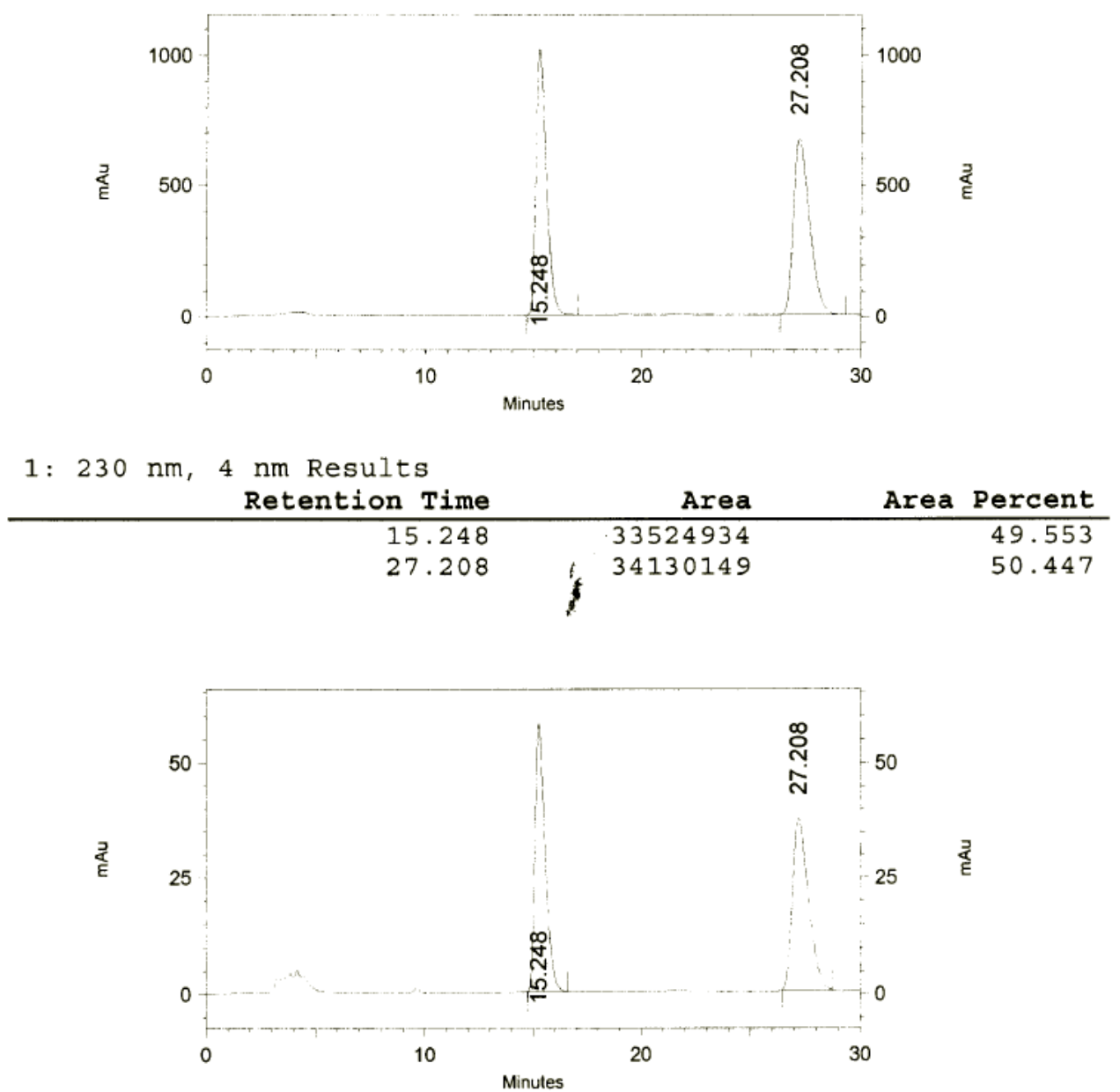

$\begin{array}{rrr}2: 254 \mathrm{~nm}, 4 \mathrm{~nm} \text { Results } & \text { Area } & \text { Area Percent } \\ \text { Retention Time } & 1860630 & 50.168 \\ 15.248 & 1848133 & 49.832\end{array}$




\section{Chromatogram - Table 2, Entry 2 (resolved)}

\begin{tabular}{|c|c|}
\hline $\begin{array}{l}\text { Sample ID: } \\
\text { Filename: } \\
\text { 8-36-48 PMCMM_OD90 } \\
\text { C: \EzStart \Project } \\
\text { Injection volume: }\end{array}$ & $\begin{array}{l}\text { Isolated_p-OMe_alcohol } \\
\text { C: } \backslash \text { EzStart } \backslash \text { Projects } \backslash \text { Default } \backslash \text { Data } \backslash \text { Christine } \backslash 9-7-2004 \\
\text { met.dat Method: } \\
\text { ault } \backslash \text { Method } \backslash \text { Christine } \backslash \text { CMM_oD9010IP.met } \\
10 \mathrm{uL}\end{array}$ \\
\hline
\end{tabular}

Description: \{Data Description\}

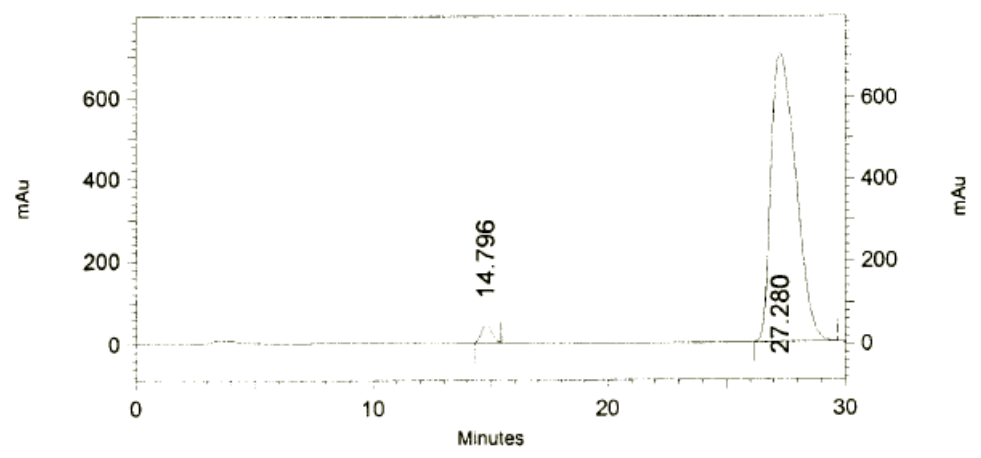

1: $230 \mathrm{~nm}, 4 \mathrm{~nm}$ Results

Retention Time

Area

Area Percent

14.796

1250105

27.280

50720679

97.595

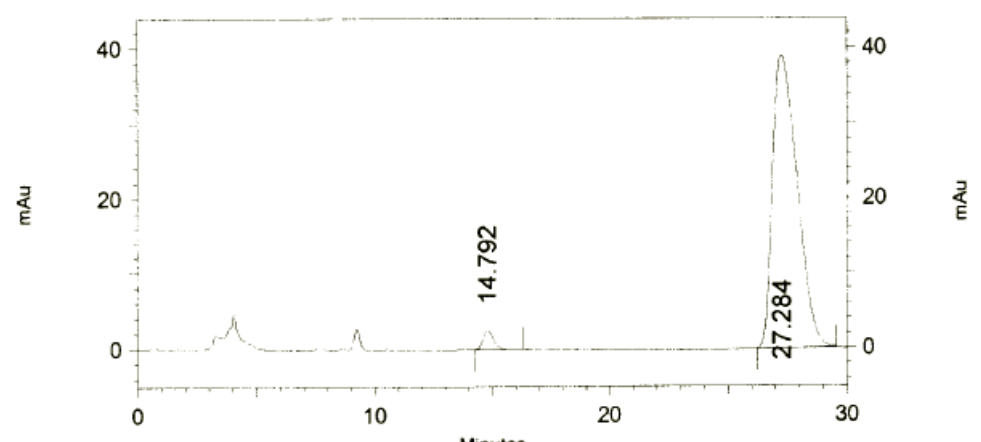

2: $254 \mathrm{~nm}, 4 \mathrm{~nm}$ Results

Retention Time

Area

Area Percent

14.792

78492

2801256

2.726

27.284

2801256

97.274 


\section{Chromatogram - Table 2, Entry 3 (racemic)}

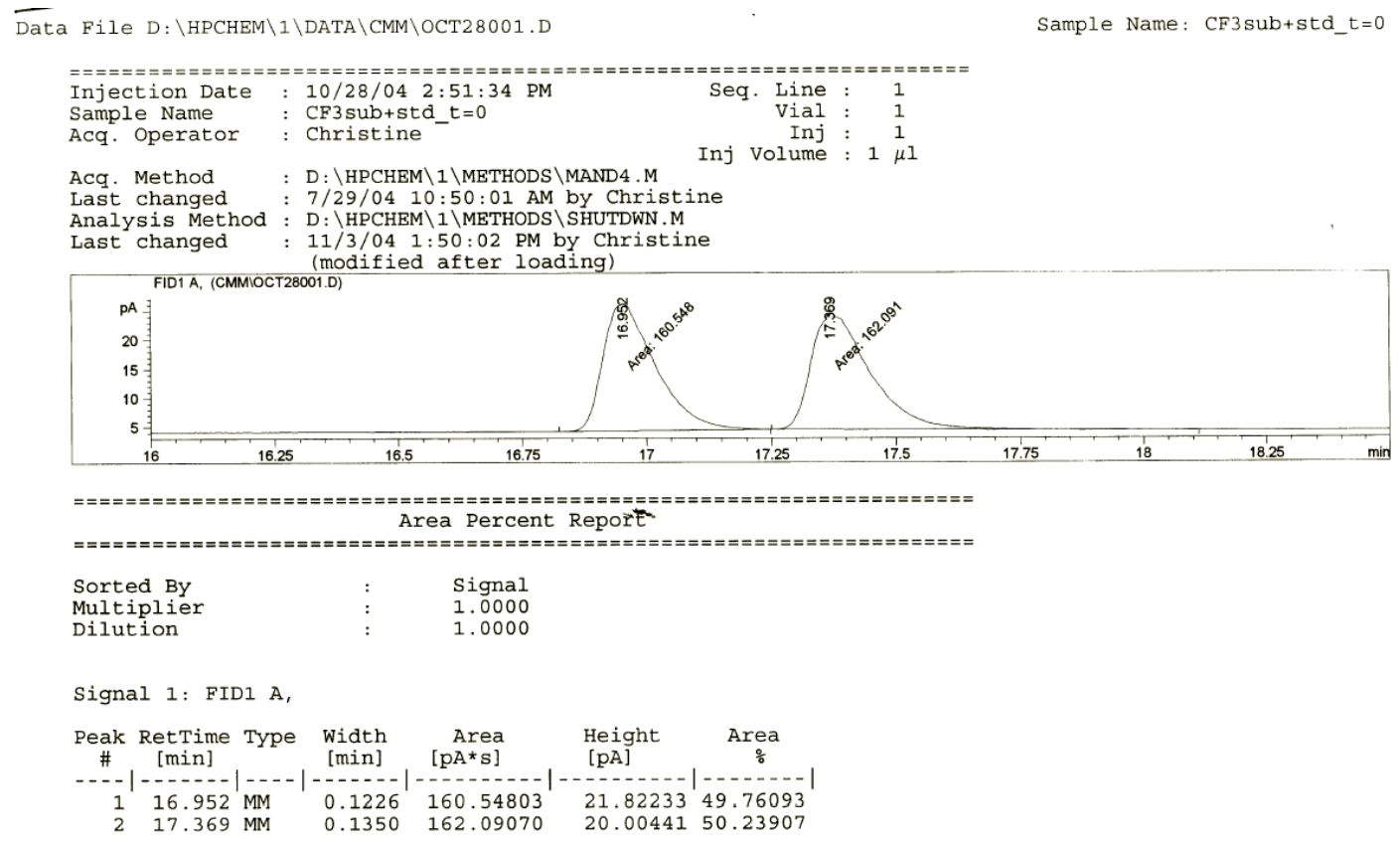

\section{Chromatogram - Table 2, Entry 3 (resolved)}

File $D: \backslash H P C H E M \backslash 1 \backslash D A T A \backslash C M M \backslash O C T 28004$.D
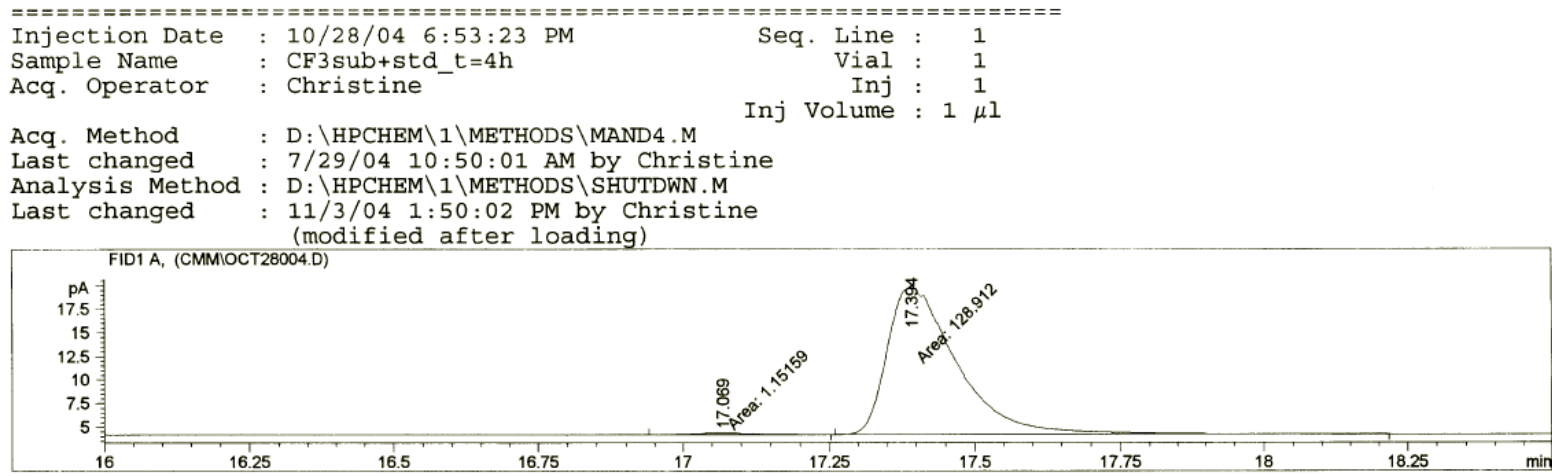

\begin{tabular}{|c|c|c|}
\hline Sorted By & : & Signal \\
\hline Multiplier & : & 1.0000 \\
\hline Dilution & : & 1.0000 \\
\hline
\end{tabular}

Signal 1: FID1 A,

\begin{tabular}{|c|c|c|c|c|c|c|}
\hline eak & $\begin{array}{l}\text { RetTime } \\
\text { [min] }\end{array}$ & Type & $\begin{array}{l}\text { Width } \\
\text { [min] }\end{array}$ & $\begin{array}{c}\text { Area } \\
{[\mathrm{pA} * \mathrm{~s}]}\end{array}$ & $\begin{array}{l}\text { Height } \\
{[\mathrm{pA}]}\end{array}$ & $\begin{array}{c}\text { Area } \\
\frac{\circ}{6}\end{array}$ \\
\hline & & & & & & \\
\hline 2 & 17.3 & M & 0. & 128.91240 & 30259 & \\
\hline
\end{tabular}




\section{Chromatogram - Table 2, Entry 4 (racemic)}

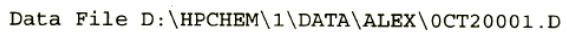
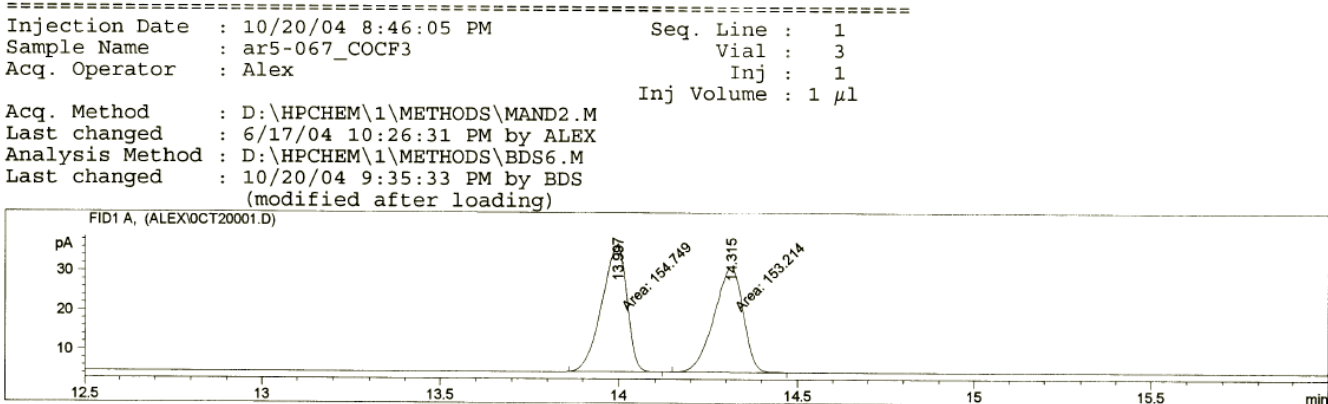

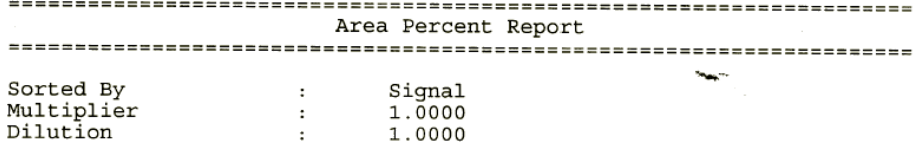

Signal 1: FID1 A,

\begin{tabular}{|c|c|c|c|c|c|c|}
\hline $\begin{array}{c}\text { Peak } \\
\#\end{array}$ & $\begin{array}{l}\text { RetTime } \\
\text { [min] }\end{array}$ & Type & $\begin{array}{l}\text { Width } \\
\text { [min] }\end{array}$ & $\begin{array}{r}\text { Area } \\
{\left[\mathrm{pA}^{*} \mathrm{~s}\right]}\end{array}$ & $\begin{array}{l}\text { Height } \\
{[\mathrm{pA}]}\end{array}$ & $\begin{array}{c}\text { Area } \\
\frac{\circ}{0}\end{array}$ \\
\hline $\begin{array}{l}1 \\
2\end{array}$ & $\begin{array}{l}13.997 \\
14.315\end{array}$ & $\begin{array}{l}\text { MM } \\
\text { MM }\end{array}$ & $\begin{array}{l}0.0791 \\
0.0948\end{array}$ & $\begin{array}{l}154.74883 \\
153.21353\end{array}$ & $\begin{array}{l}32.60118 \\
26.93303\end{array}$ & $\begin{array}{l}50.24927 \\
49.75073\end{array}$ \\
\hline otal & & & & 307.96236 & 59.53421 & \\
\hline
\end{tabular}

Results obtained with enhanced integrator

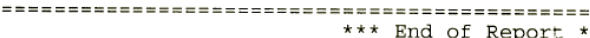

\section{Chromatogram - Table 2, Entry 4 (resolved)}

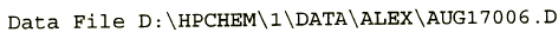
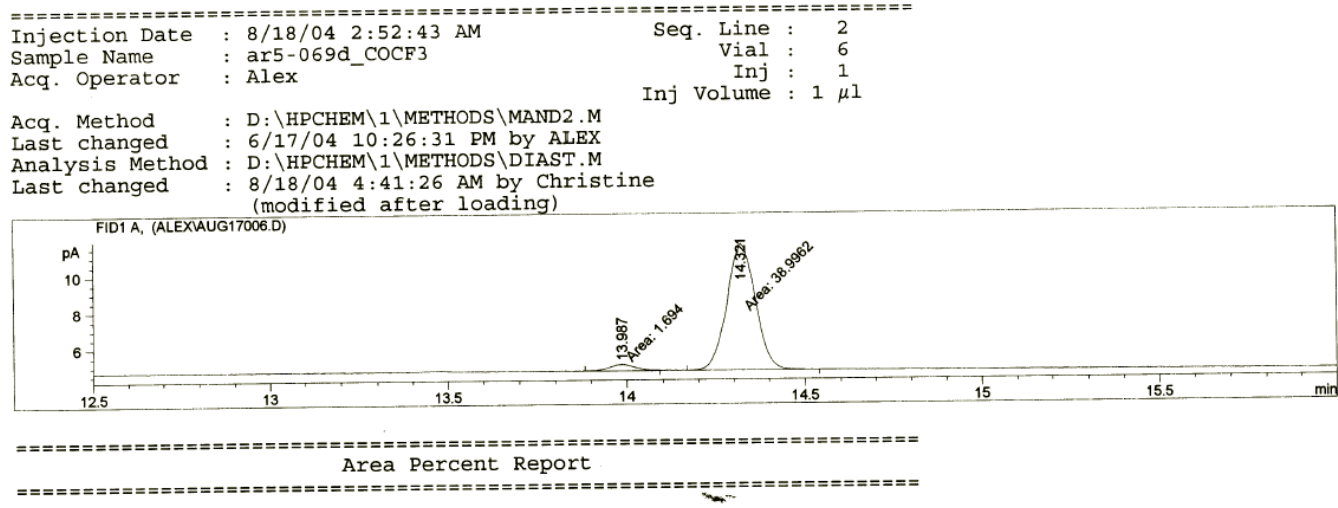

$\begin{array}{lll}\text { Sorted By } & : & \text { Signal } \\ \text { Multiplier } & : & 1.0000 \\ \text { Dilution } & : & 1.0000\end{array}$

Signal 1: FID1 A,

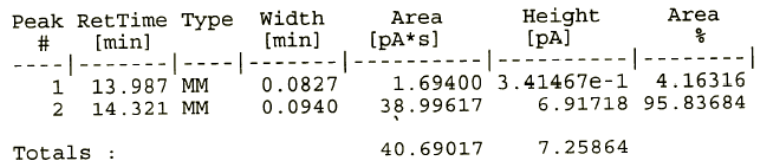

Results obtained with enhanced integrator!

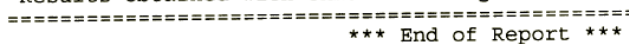




\section{Chromatogram - Table 2, Entry 5 (racemic)}

Data File D: \HPCHEM \1\DATA \ALEX \JUL19003.D
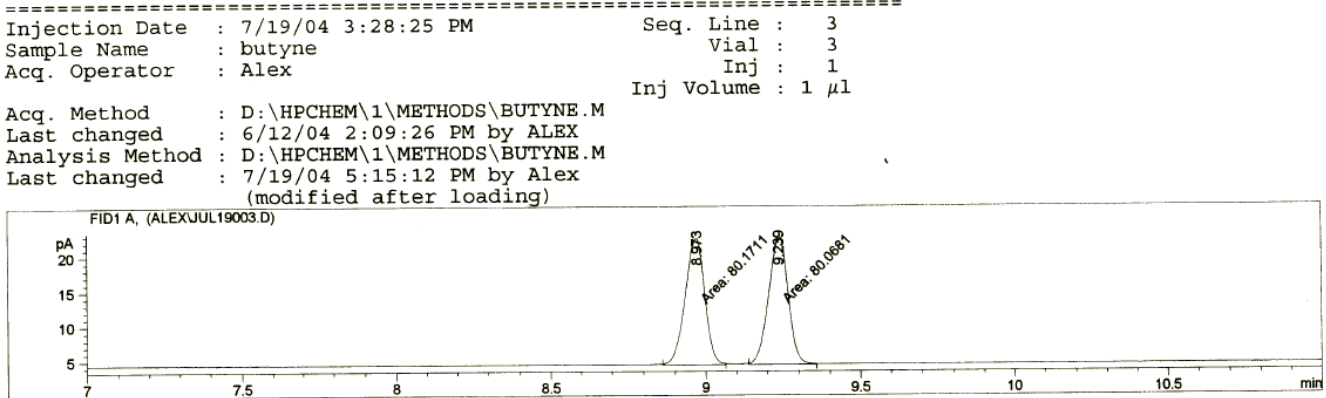

\begin{tabular}{|c|c|}
\hline Sorted By & Signal \\
\hline Multiplier & 1.0000 \\
\hline Dilution & 1.0000 \\
\hline
\end{tabular}

Signal 1: FID1 A,

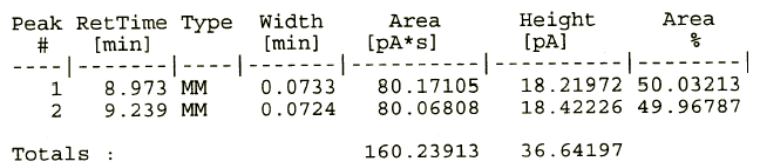

Results obtained with enhanced integrator!

$\star \star================$
$\star \star \star$ End of Report $\star \star \star$

\section{Chromatogram - Table 2, Entry 5 (resolved)}

Data File D: \HPCHEM $\backslash 1 \backslash$ DATA \ALEX \OCT25002.D
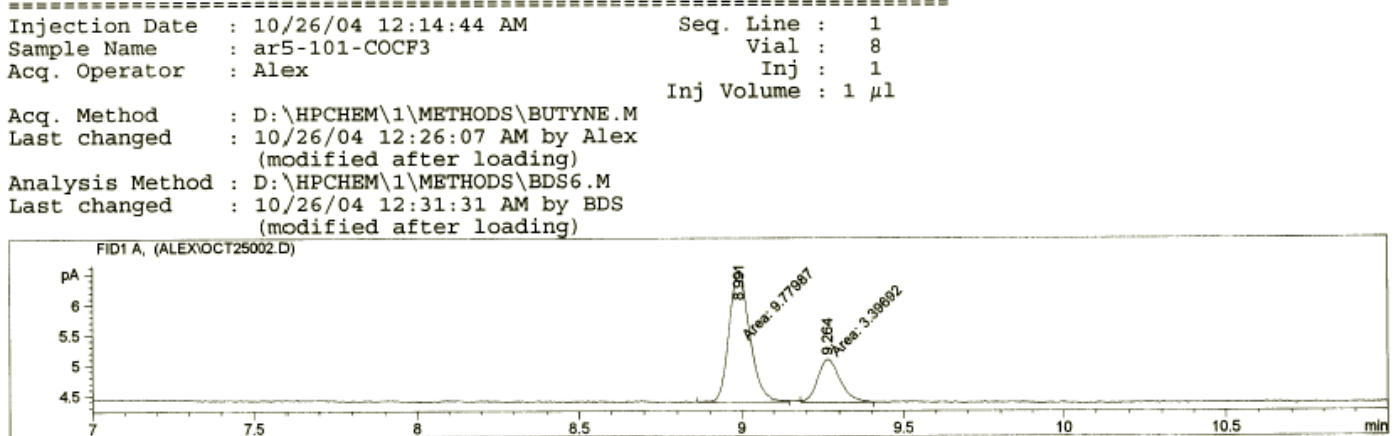

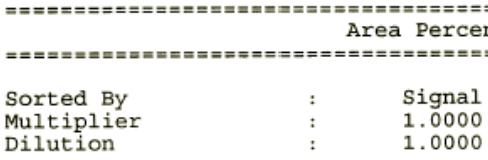

Signal 1: FID1 A,

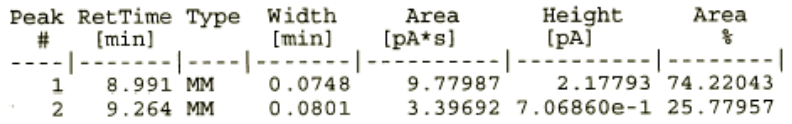




\section{Chromatogram - Table 2, Entry 6 (racemic)}

Data File D: \HPCHEM \I\DATA \ALEX \JUL04004.D

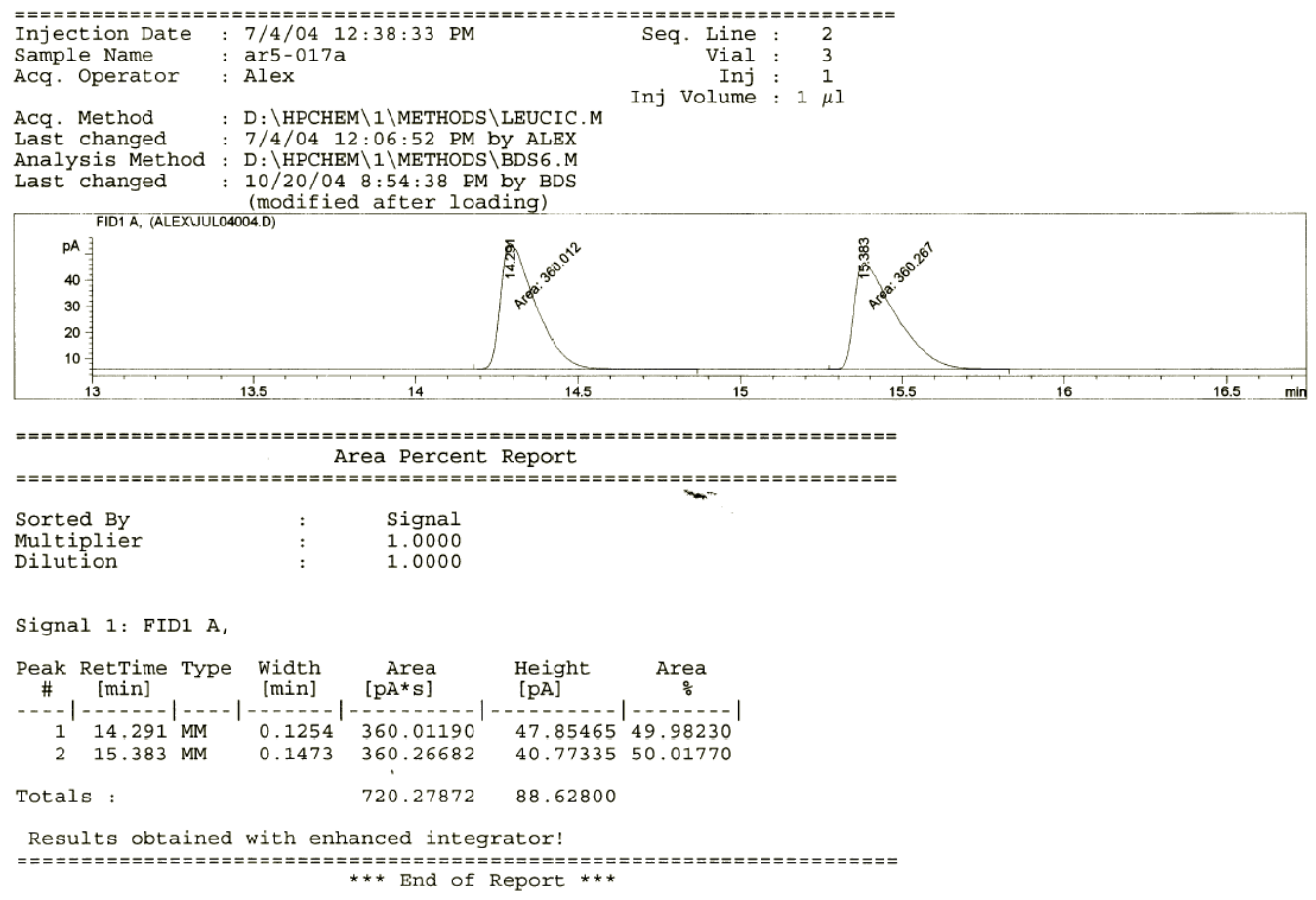

\section{Chromatogram - Table 2, Entry 6 (resolved)}

Data File D: \HPCHEM \1\DATA \ALEX \JUL18001.D

Sample Name: ar5-019e

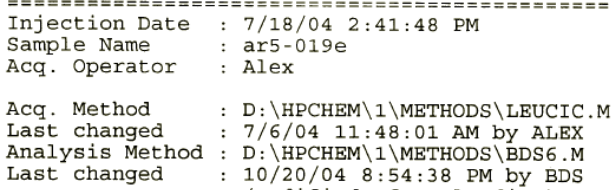




\section{Chromatogram - Table 2, Entry 7 (racemic)}

Data File D: \HPCHEM \1\DATA \ALEX \JUL30006.D

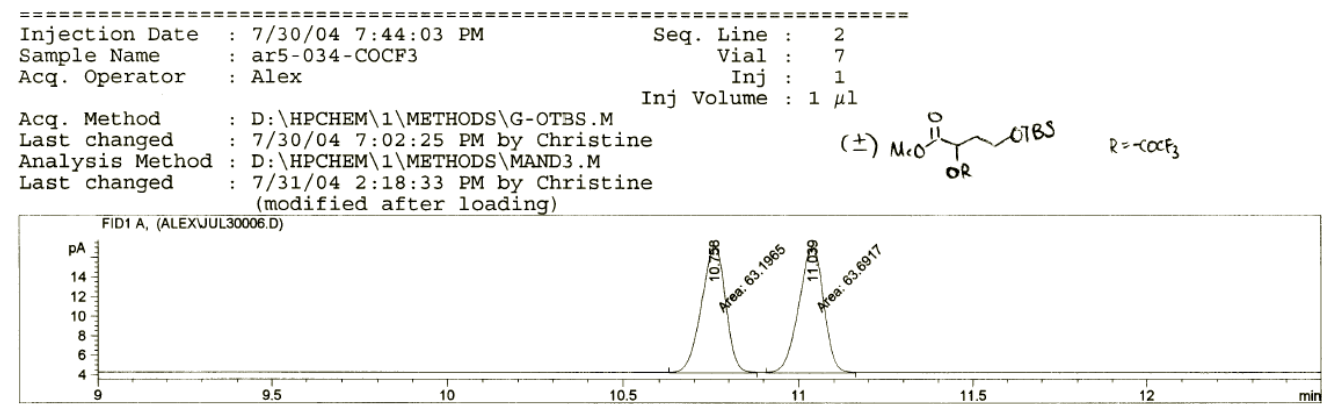

\begin{tabular}{|c|c|c|}
\hline Sorted By & : & Signal \\
\hline Multiplier & : & \\
\hline Dilution & : & 1.000 \\
\hline
\end{tabular}

Signal 1: FID1 A

\begin{tabular}{|c|c|c|c|c|c|c|}
\hline $\begin{array}{c}\text { Peak } \\
\#\end{array}$ & $\begin{array}{l}\text { RetTime } \\
\text { [min] }\end{array}$ & Type & $\begin{array}{l}\text { Width } \\
\text { [min] }\end{array}$ & $\begin{array}{r}\text { Area } \\
{\left[\mathrm{pA}^{\star} \mathrm{s}\right]}\end{array}$ & $\begin{array}{l}\text { Height } \\
\text { [pA] }\end{array}$ & $\begin{array}{c}\text { Area } \\
\frac{\circ}{0}\end{array}$ \\
\hline 1 & 10.758 & MM & 0.0816 & 63.19650 & 12.90050 & 49.80486 \\
\hline 2 & 11.039 & MM & 0.0822 & 63.69172 & 12.91580 & 50.19514 \\
\hline Tota & & & & 126.88822 & 25.81630 & \\
\hline
\end{tabular}

Results obtained with enhanced integrator!

$$
\begin{aligned}
& =================== \\
& \star \star \star \text { End of Report } \star \star \star
\end{aligned}
$$

\section{Chromatogram - Table 2, Entry 7 (resolved)}

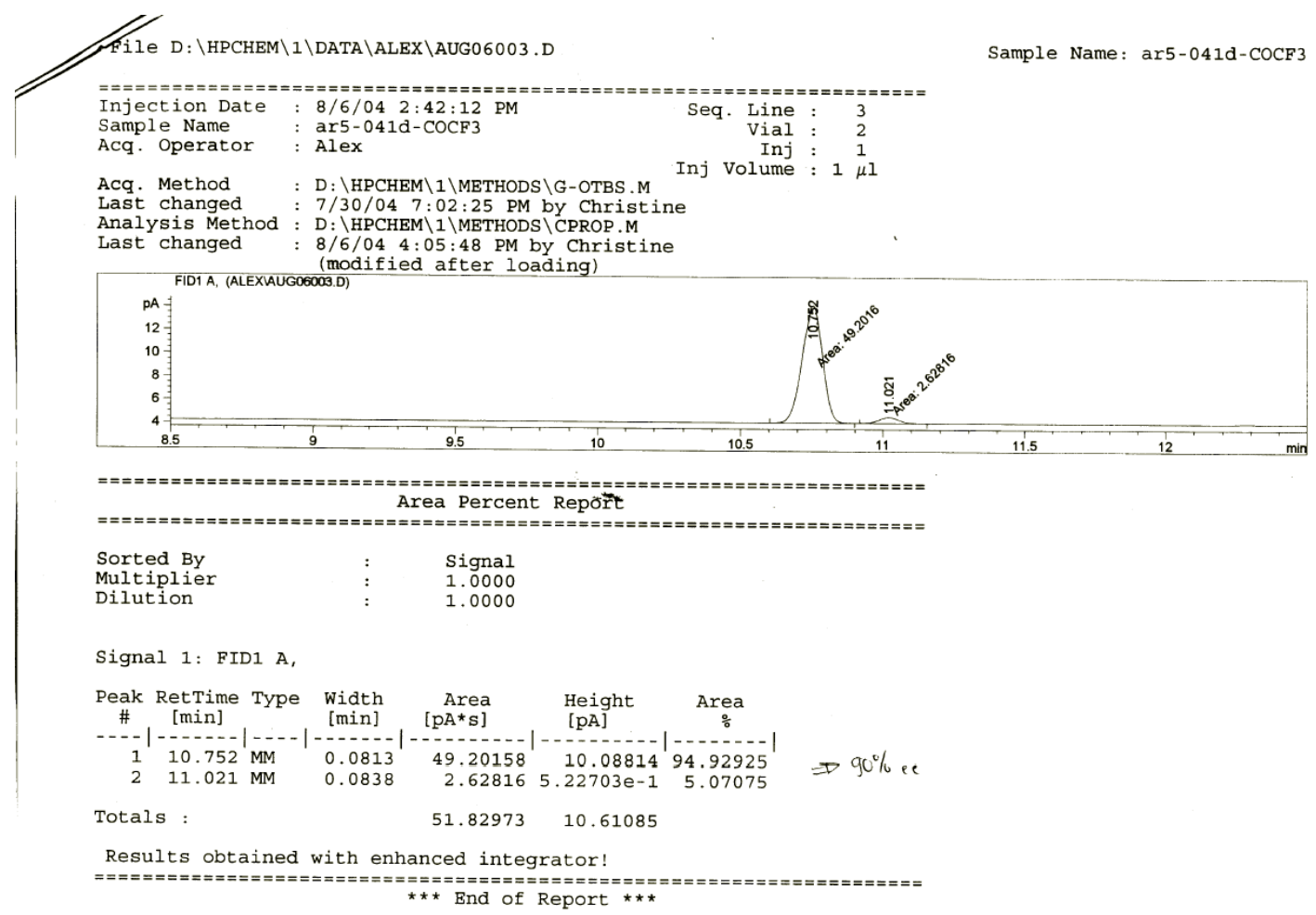




\section{Chromatogram - Table 2, Entry 8 (racemic)}

\begin{tabular}{|cc|}
\hline Sample ID: & ar5-076 \\
Filename: & C: $\backslash$ EZStart $\backslash$ Projects $\backslash$ Default $\backslash$ Data $\backslash$ Alex $\backslash 9-1-2004$ \\
4-43-39 PMar_oJ9307IP. met.dat & Method: \\
C: $\backslash$ EzStart $\backslash$ Projects $\backslash$ Default $\backslash$ Method $\backslash$ Alex $\backslash$ ar_OJ9307IP.met \\
Injection volume: & $5 \mathrm{uL}$ \\
\hline
\end{tabular}

Description: \{Data Description\}
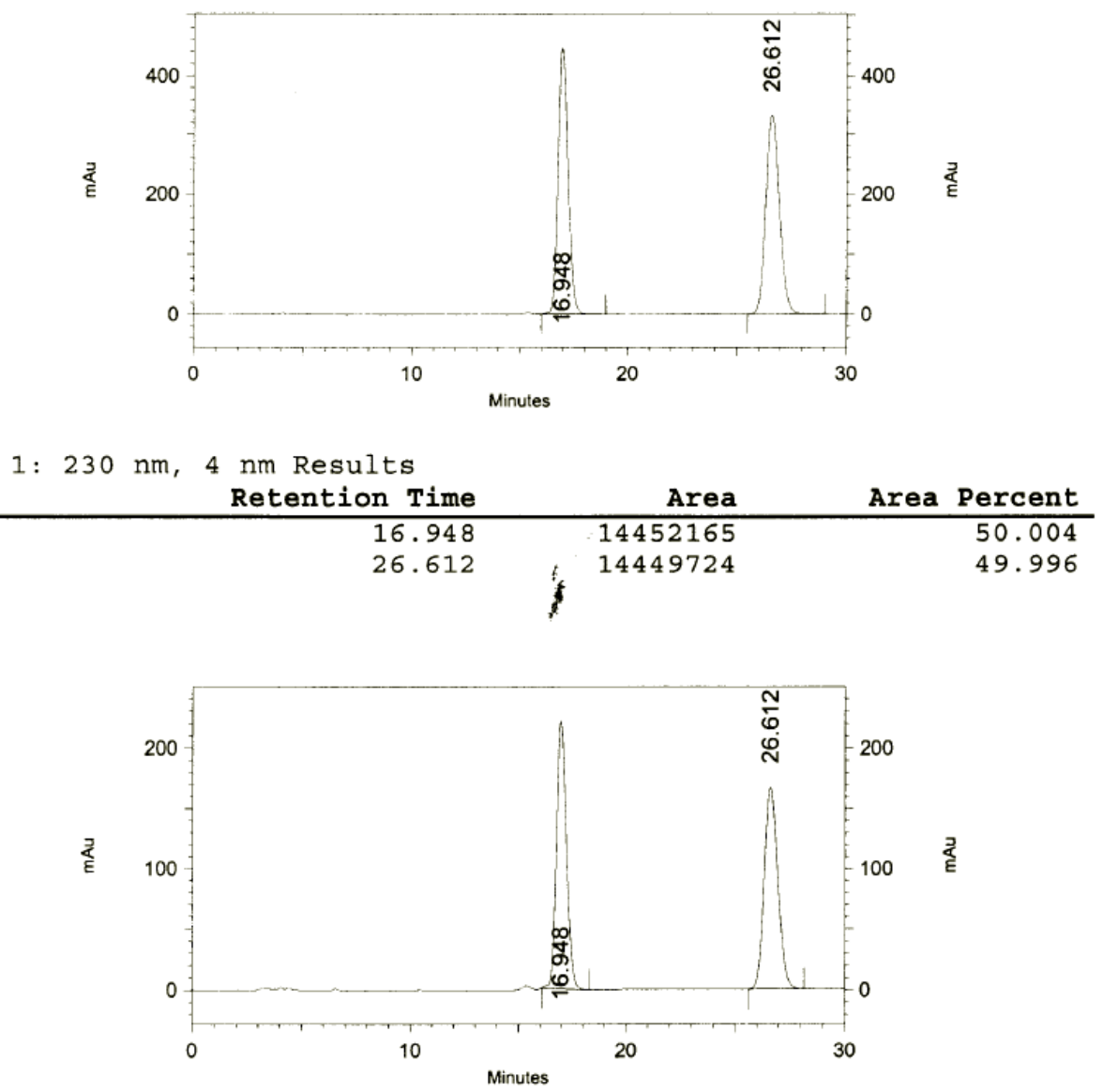

2: $254 \mathrm{~nm}, 4 \mathrm{~nm}$ Results 
Chromatogram - Table 2, Entry 8 (resolved)

\begin{tabular}{|cc|}
\hline Sample ID: & ar5-099 \\
Filename: & C $: \backslash$ EZStart $\backslash$ Projects $\backslash$ Default $\backslash$ Data $\backslash$ Alex $\backslash 10-21-2004$ \\
6-24-50 PMar_OJ9307IP. met.dat & Method: \\
C: $\backslash$ EZStart $\backslash$ Projects $\backslash$ Default $\backslash$ Method $\backslash$ Alex $\backslash$ ar_OJ9307IP. met \\
Injection volume: & $5 \mathrm{uL}$ \\
\hline
\end{tabular}

Description: \{Data Description\}

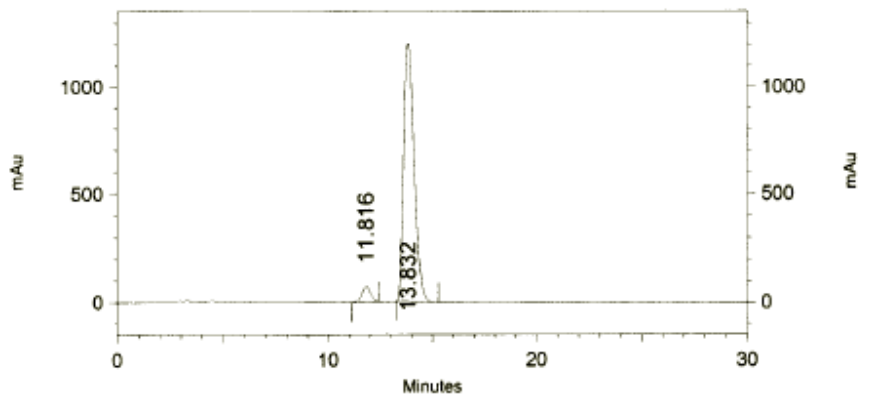

1: $230 \mathrm{~nm}, 4 \mathrm{~nm}$ Results

Retention Time

11.816

13.832

Area

Area Percent

\begin{tabular}{rrr} 
Retention Time & Area & Area Percent \\
\hline 11.816 & 2085338 & 4.779 \\
13.832 & 41552311 & 95.221
\end{tabular}

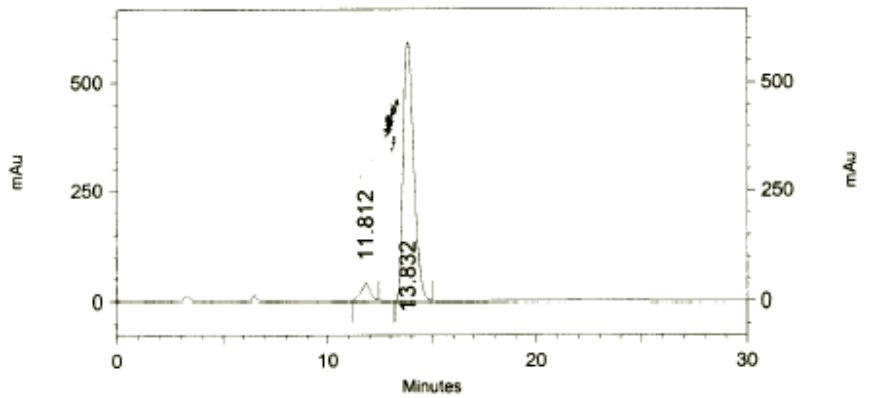

2: $254 \mathrm{~nm}, 4 \mathrm{~nm}$ Results

Retention Time

Area

Area Percent

11.812

1229942

5.612

13.832

20684512

94.388 


\section{Chromatogram - Table 2, Entry 9 (racemic)}

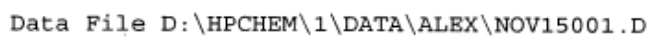
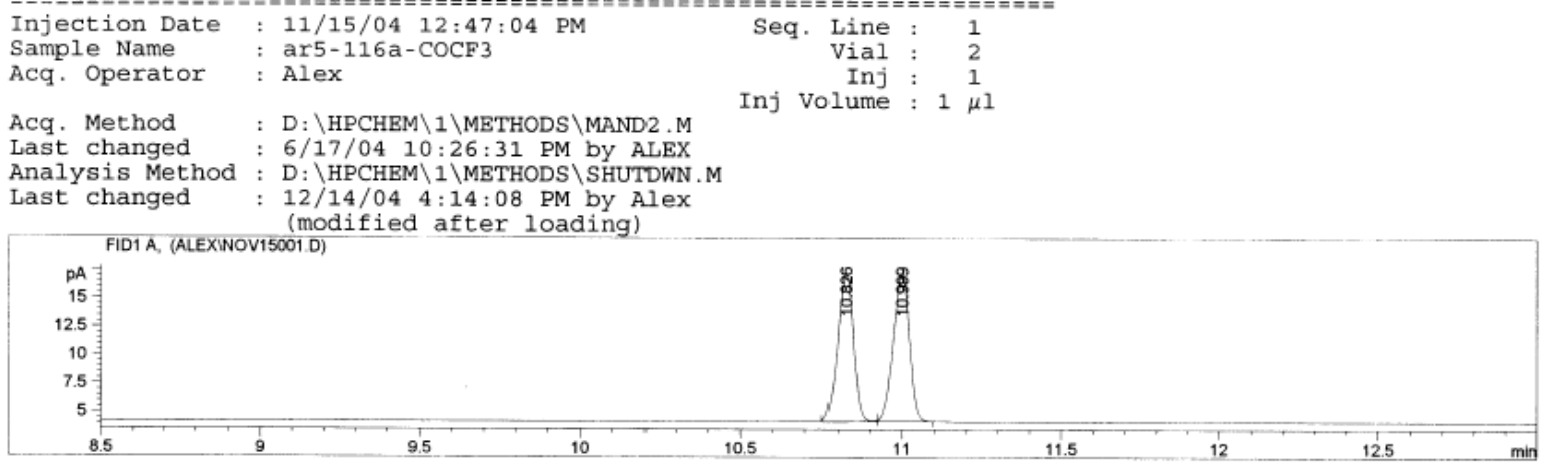

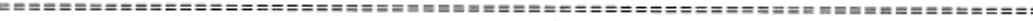

Area Percent Report

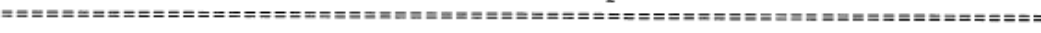

$\begin{array}{lll}\text { Sorted By } & : & \text { Signal } \\ \text { Multiplier } & : & 1.0000\end{array}$

$\begin{array}{lll}\text { Multiplier } & : & 1.0000 \\ \text { Dilution } & : & 1.0000\end{array}$

Signal 1: FID1 A,

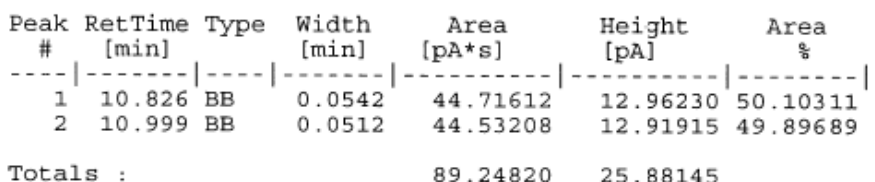

Totals :

$89.24820 \quad 25.88145$

\section{Chromatogram - Table 2, Entry 8 (resolved)}

Data File D: $\backslash$ HPCHEM $\backslash 1 \backslash D A T A \backslash A L B X \backslash D E C 02001 . D$

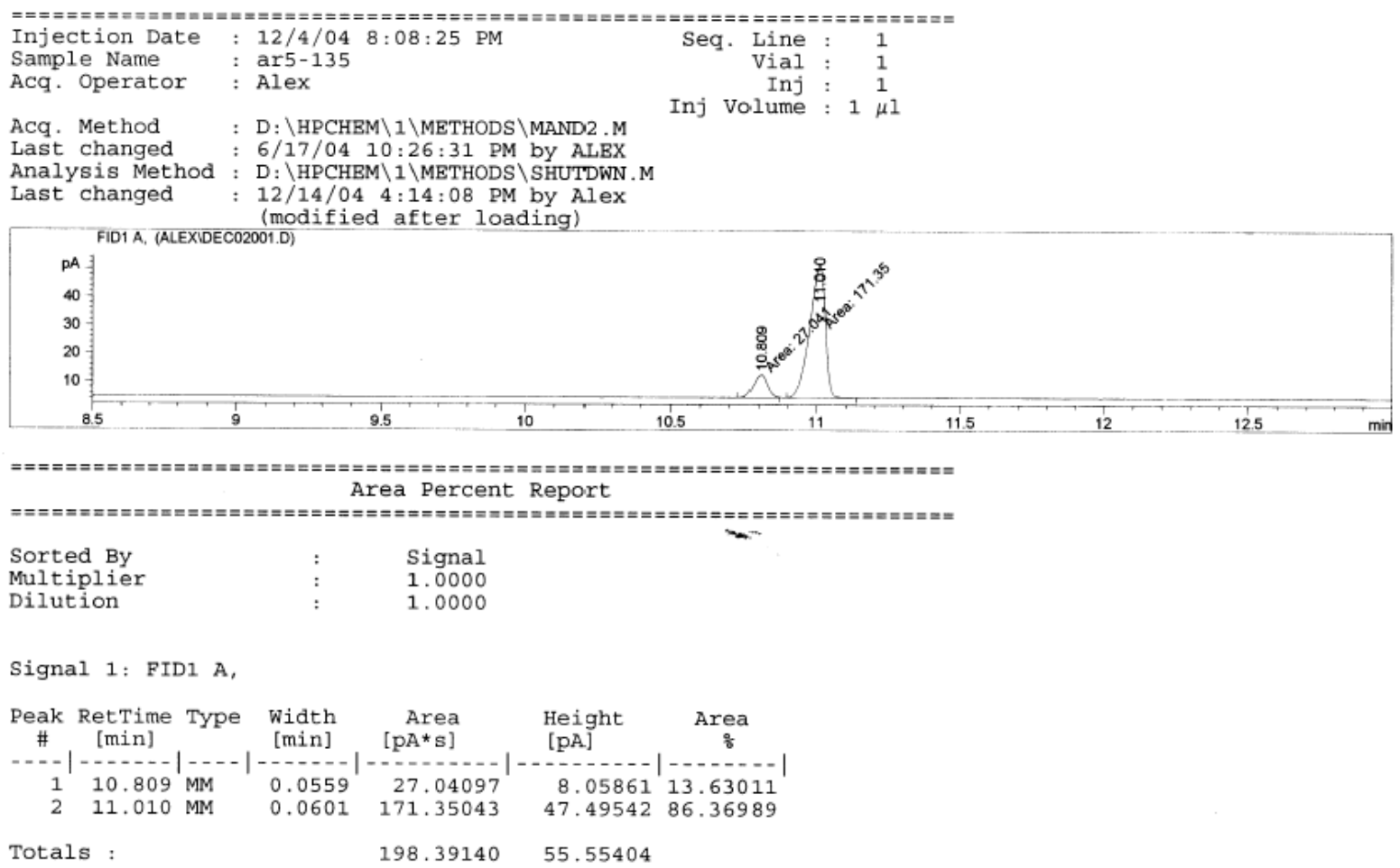

